\title{
Microneedle systems for delivering nucleic acid drugs
}

\author{
Inhwan Noh $^{1} \cdot$ Kyuri Lee ${ }^{1} \cdot$ Yun-Seok Rhee ${ }^{1}$ (]) \\ Received: 8 September 2021 / Accepted: 24 December 2021 / Published online: 4 January 2022 \\ (c) The Author(s) under exclusive licence to The Korean Society of Pharmaceutical Sciences and Technology 2022
}

\begin{abstract}
Background Nucleic acid-based gene therapy is a promising technology that has been used in various applications such as novel vaccination platforms for infectious/cancer diseases and cellular reprogramming because of its fast, specific, and effective properties. Despite its potential, the parenteral nucleic acid drug formulation exhibits instability and low efficacy due to various barriers, such as stability concerns related to its liquid state formulation, skin barriers, and endogenous nuclease degradation. As promising alternatives, many attempts have been made to perform nucleic acid delivery using a microneedle system. With its minimal invasiveness, microneedle can deliver nucleic acid drugs with enhanced efficacy and improved stability.

Area covered This review describes nucleic acid medicines' current state and features and their delivery systems utilizing non-viral vectors and physical delivery systems. In addition, different types of microneedle delivery systems and their properties are briefly reviewed. Furthermore, recent advances of microneedle-based nucleic acid drugs, including featured vaccination applications, are described.

Expert opinion Nucleic acid drugs have shown significant potential beyond the limitation of conventional small molecules, and the current COVID-19 pandemic highlights the importance of nucleic acid therapies as a novel vaccination platform. Microneedle-mediated nucleic acid drug delivery is a potential platform for less invasive nucleic acid drug delivery. Microneedle system can show enhanced efficacy, stability, and improved patient convenience through self-administration with less pain.
\end{abstract}

Keywords Microneedle $\cdot$ Nucleic acid $\cdot$ mRNA $\cdot$ siRNA $\cdot$ Vaccination

\section{Introduction}

Gene therapy is a promising technology for treating lifethreatening diseases by engineering a specific gene target (Mulligan 1993). In response to the recent COVID-19 pandemic, DNA and mRNA vaccines have been shown the utility of nucleic acid-based vaccines with a rapid response to emerging infectious diseases as safe and useful treatment options (Haynes 2021; Dagan et al. 2021). In addition, nucleic acid drug has been demonstrated to have a great potential for decades as a cancer vaccine that may not be achievable with conventional vaccine approaches (including

Yun-Seok Rhee ysrhee@gnu.ac.kr

1 College of Pharmacy and Research Institute of Pharmaceutical Sciences, Gyeongsang National University, 501 Jinjudae-ro, Jinju, Gyeongsangnam-do 52828, Republic of Korea previous small molecules and protein-based therapeutics approach or tools) for cellular reprogramming or trans-differentiation (Kwon et al. 2018; Pardi et al. 2018; Hu et al. 2020; Morshed et al. 2020).

Despite its potential, delivering a nucleic acid to target sites such as the nucleus and the cytoplasm inside the cell of target tissues faces several hurdles due to its charged and macromolecular nature (McCaffrey et al. 2015; Hu et al. 2020). First, an exogeneous nucleic acid medication must pass through the skin's tight junctions and then the cell membrane or nucleus. Then it needs to resist degradation by endogenous enzymes such liver metabolism and nucleases until its internalization into the cell (Sorrentino 2010). As a result, it relies on a drug delivery system that can protect against nuclease and protein binding while allowing for enhanced membrane penetration (McCaffrey et al. 2015; Pardi et al. 2018; Hu et al. 2020). Many previous studies on nucleic acid medicines have employed intramuscular or subcutaneous injection as a parenteral method coupled 
with nanocarriers (Pardi et al. 2018; Hu et al. 2020). However, these parenteral injection routes might be unpleasant (I-Hong Hsu 2016). In addition, they need medical personnel to perform the injection. Furthermore, nucleic acid medicines are less stable since the medication must be reconstituted in a liquid form prior to injection, which may present distribution, storage, and shelf-life concerns. Significant stability issues of mRNA vaccines for COVID have recently been addressed in this respect (Schoenmaker et al. 2021).

Microneedle (MN) can be used as one promising approach for nucleic acid delivery. As one of transdermal drug delivery systems, MN can create physical channels for drugs to bypass the stratum corneum layer, which serves as a strong barrier for transdermal administration. With a minimally invasive manner, $\mathrm{MN}$ system allows nucleic acid penetration and self-application. It also improves patient compliance by enhancing user convenience due to its simple application technique with reduced discomfort compared to parenteral preparations. It also has the benefit of improved stability of drugs because drugs are encapsulated in a dried state (Pearton et al. 2012; Liao et al. 2017; Schoenmaker et al. 2021).

This review examines the current state and characteristics of nucleic acid drugs and delivery systems, as well as a brief overview of the various types and characteristics of microneedle systems. Recent advancements in MN-based nucleic acid drugs for vaccination against infectious diseases or cancer are also discussed. Furthermore, research on microneedle formulation and morphology, as well as combination approaches of microneedles with other delivery systems, is reviewed as strategies to improve the transfection efficacy of microneedle-based nucleic acids. Finally, limitations and factors to consider when developing microneedles for nucleic acid delivery are discussed.

\section{Nucleic acid drugs}

\section{Plasmid DNA}

Plasmid is a circular double-stranded DNA molecule that originates from the cytoplasm of bacteria (Wolff et al. 1990). It can be applied to gene therapy by expressing target protein in cells. It has the advantages of easy handling (such as storage and transport due to its high stability) and easy mass production. As a DNA vaccine, it can be used for treating infectious disease or cancer by encoding tumor-associated antigen (Lopes et al. 2019; Eusébio et al. 2021). Plasmid DNA has been studied in various applications such as regenerative medicine using induced pluripotent stem cells (iPSCs) by transfecting plasmid DNA encoding reprogramming factors like Yamanaka factor (Karow et al. 2011).
However, because plasmid DNA may contain bacteriaderived foreign genes, it may induce adverse effects such as inflammation (Yew et al. 2000). Furthermore, it faces an issue of poor transfection efficiency that needs to be addressed. Researchers have utilized viral vectors, non-viral vectors, and physical delivery system to improve its transfection efficiency (Chen et al. 2016).

In the case of using a viral vector, it may show a relatively high expression level. However, it has limited payload due to the size of the viral vector with a poor productivity (McClements and Maclaren 2017). Additionally, immunogenicity of viral vector itself limits repeated administration such as boost inoculations (Hardee et al. 2017). More critically, the viral-vector delivery system has shown significant risks of potential insertion mutation and carcinogenicity. As an alternative, a non-viral vector using cationic polymer or lipid nanoparticles can alleviate immunogenicity and decrease safety concerns associated with a viral vector (Schleef 2013; Hardee et al. 2017). However, it also has the issue of low expression efficiency that needs to be addressed. Recent achievements in non-viral vectors and physical delivery systems have enhanced the transfection efficiency and reduced the toxicity (Hardee et al. 2017; Kulkarni et al. 2018).

\section{SiRNA}

In 1998, Fire et al. discovered that RNA interference (RNAi) could be utilized for gene therapy (Fire et al. 1998). siRNA can mediate target mRNA degradation by forming RNA-molecules induced Silencing Complex (RISC) in a sequence-specific manner, followed by knock-down expression of a target gene encoding a protein (Setten et al. 2019; $\mathrm{Hu}$ et al. 2020). Unlike monoclonal antibodies or small molecules medicines designed to recognize complex structures of target proteins using screening technologies such as structure activity relationship (SAR), siRNA can inhibit a specific mRNA with a sequence-specific manner, allowing researcher to target specific genes of interest (Zhang et al. 2021). Therefore, siRNA can be applied to treat a wide spectrum of diseases with a comparatively short development period (Hu et al. 2020).

However, in the early stage of research on siRNA-based therapies, systematically administered siRNA without a carrier (naked) was rapidly degraded by nuclease and rigorously excreted owing to its small size, resulting in poor pharmacokinetics and low efficacy (Huang et al. 2011). siRNA shows immunostimulatory properties by binding to pattern recognition receptors (PRRs) such as TLR3 at several locations (for example surface of target cell, endosomal, or cytosol level), which induces adverse effects such as inflammation (Cho et al. 2009). Furthermore, siRNA may face difficulties of escaping from the endosome or lysosome 
to the cytoplasm after siRNA enter the cell, it may show a low efficiency (Kim et al. 2019; Hu et al. 2020).

These difficulties can be alleviated by the development of chemical modification and delivery systems such as nanocarriers, which can protect systemically administered siRNA from various degrading enzymes or serum protein binding, thus greatly improving its stability and pharmacokinetic behaviors (Khvorova and Watts 2017; Setten et al. 2019; $\mathrm{Hu}$ et al. 2020). These developments have also increased siRNA intracellular permeability with improved efficacy. As a result, various therapeutics using advanced siRNA system have been reported, including cancer therapy. ONPATTRO ${ }^{\circledR}$ (Patisiran), the first authorized siRNA medicine, was successfully introduced in 2018, demonstrating the promise of siRNA treatment, followed by GIVLAARI ${ }^{\circledR}$ (Givosiran) in 2019 and OXLUMO ${ }^{\circledR}$ (Lumasiran) in 2020, all of which were successfully commercialized. Recently, the European Commission (EC) approved LEQVIO ${ }^{\circledR}$ (inclisiran) for the treatment of adults with hypercholesterolemia or mixed dyslipidemia. In September 2021, LEQVIO® received NICE (National Institute for Health and Care Excellence) approval for use by the National Health Service in the UK. Most of siRNA medicines including many other siRNA candidates in clinical trials are targeting rare diseases or diseases that urgently need novel and effective therapies (Zhang et al. 2021).

\section{mRNA}

mRNA is a single-stranded RNA that encodes proteins. It usually has a rapid onset and better protein expression than plasmid DNA because protein expression from mRNA through translation is feasible at the cytoplasm level, as opposed to pDNA which must enter the nucleus (Kwon et al. 2018; Liu 2019). In addition, it is safe since mRNA poses no potential risk of insertional mutagenesis or carcinogenesis shown in plasmid DNA treatment. mRNA is finally degraded by endogenous enzymes inside or outside of cells.

However, like an siRNA, the intrinsic poor stability of mRNA limits its applications in its early stage of development (Kwon et al. 2018). mRNA can also induce immune responses due to its innate immunostimulatory properties by stimulating several pattern recognition receptors (PRRs) such as TLR7 and TLR8 on the cell surface and endosomal levels (Heil 2004; Pardi et al. 2018). These immunological properties can also lead to decreased expression levels of mRNA caused by type- 1 interferon secretion (Pardi et al. 2018). Furthermore, an efficient synthesis method of mRNA is lacking. As a result, mRNA has not received much attention compared to other nucleic acid drugs in the early stage of gene therapy development.

In the 1990s, along with the development of a simple and efficient method for in vitro transcription (IVT) of mRNA
(Wolff et al. 1990; Sahin et al. 2014), the stability and efficacy of mRNA were much improved by introducing chemically modified nucleosides or nanocarrier complexes, similar to siRNA (Karikó et al. 2008; Kwon et al. 2018). Furthermore, expression efficiency could be greatly increased by sequence optimization each structure of mRNA (for example, 3' and 5' untranslated regions and poly A tail) (Kwon et al. 2018) and minimizing immune stimulation caused by dsRNA contamination through additional purification such as size exclusive chromatography (Karikó et al. 2011). In recent years, these advances have made mRNA a promising alternative to plasmid DNA. Through global inoculation, the safety and efficacy of mRNA vaccines have been considerably established (Polack et al. 2020). Not only mRNA vaccines for infectious diseases, but also mRNA technologies can be applied as regenerative medicine via induced pluripotent stem cells or cancer vaccines using tumor-associated antigen encoding mRNA in a sequence-specific manner, showing significant potential and feasibility of gene therapy (Kwon et al. 2018; Pardi et al. 2018).

\section{Nucleic acid drug delivery}

To be effective, a nucleic acid drug should enter the body via a parenteral route and permeate the lipid membrane barrier of the cell so that it could be delivered to its site of action such as the cytoplasm or nucleus (McCaffrey et al. 2015; Hu et al. 2020). Although researchers have discovered several types of cells that can absorb nucleic acids, permeation of nucleic acid into cells is regarded a difficult process for most cells due to characteristics of nucleic acid such as a large size and surface charge. Therefore, a well-designed delivery system for nucleic acid to reach the target cell is a critical element that affects its clinical efficacy (McCaffrey et al. 2015; Pardi et al. 2018; Hu et al. 2020).

\section{Injection of naked nucleic acid drug}

A naked nucleic acid delivery system refers to a system in which a nucleic acid drug has no covalent or non-covalent association with the delivery system. Because it is directly exposed to the environment it makes contact with, naked nucleic acid cannot be protected from various degrading enzyme or binding proteins. Thus, it can be metabolized or excreted rapidly (Huang et al. 2011; Hu et al. 2020). It is also difficult for a naked nucleic acid to permeate the cell membrane due to its negative charge and large size. Even when nucleic acid is introduced into cells, it is usually difficult to escape from the endosome or lysosome (Kim et al. 2019; Patel et al. 2019). In addition, as mentioned above, nucleic acids can activate the immune system by stimulating various PRRs at the surface, cytosol, or endosome levels, inducing 
interferon secretion, thereby causing inflammation or reducing protein expression efficiency. Therefore, to utilize naked nucleic acid, it is necessary to use chemical modified nucleosides to prevent degradation or reduce immune stimulation (Hu et al. 2020).

On the other hand, facilitated excretion of naked nucleic acid drugs by kidney allows chemically modified nucleic acids to target renal diseases (Huang et al. 2011; Hu et al. 2020). Rather than systemic injection, naked nucleic acid drugs can be administered directly into specific organs or tissues such as the eye with comparatively low excretion or low nuclease levels (Hu et al. 2020). In addition, immune stimulating properties by activating PRRs can be an effective strategy to deliver nucleic acid vaccine (Pardi et al. 2018; Hu et al. 2020).

\section{Non-viral vectors}

Non-viral vectors for the delivery of nucleic acid drugs are expected to increase efficacy of nucleic acid drugs by preventing them from degradation and renal excretion, thus facilitating transcellular delivery by endocytosis with reduced charged nature of the complex or inhibiting their interactions with non-specific plasma proteins (Ramamoorth and Narvekar 2015). They are expected to induce endosomal escape through a variety of mechanisms, including pore formation by endosomolytic agents, membrane fusion by fusogenic agents such as peptides or lipids, and an osmotic pressure-based proton-sponge mechanism (Patel et al. 2019; $\mathrm{Hu}$ et al. 2020). Non-viral vectors can be utilized with nucleic acids by forming cationic lipid/polymer complexes, cationic or ionizable lipid nanoparticles (LNPs) (Kulkarni et al. 2018), cell penetrating peptides (CPPs) such as RALA peptides (McCaffrey et al. 2016), or by bioconjugating with $\mathrm{N}$-acetylgalactosamine (GalNAc) (Hu et al. 2020). Several non-viral vectors and their characteristics are described in Table 1. The structure or composition of nanocarriers can be optimized with mRNA followed by characterization such as net charge, size, and pKa of the delivery system (Yin et al. 2013; Yang et al. 2017; Ahmad et al. 2019). These non-viral vector systems have shown enhanced efficiency for delivering nucleic acid drugs with less toxicity (Hardee et al. 2017; Kulkarni et al. 2018). Furthermore, by conjugation with a specific ligand to a nanocarrier capable of interacting with a surface receptor of a target cell, a nucleic acid drug can be more selectively delivered to a target tissue or cell, thus increasing its therapeutic efficacy and reducing side effects (Kim et al. 2014; Hu et al. 2020).

The escape of nucleic acids from endosome or lysosome into the cytoplasm in cell has been an important issue in recent years (Patel et al. 2019). Several studies have found that only a very small fraction (less than $2 \%$ ) of endocytosed nucleic acids can escape into the cytoplasm (Gilleron et al. 2013; Kim et al. 2019). Several strategies for endosomal escape have been evaluated. One of such strategies using $\mathrm{pH}$-sensitive components such as ionizable lipids has been shown to be able to enhance the escape of nucleic acids from endosome (Pack et al. 2005; Ahmad et al. 2019). Its mechanism is called proton-sponge mechanism. When the $\mathrm{pH}$ inside the endosome or lysosome changes, the $\mathrm{pH}$-sensitive unit becomes positively charged, allowing waters and ions to flow into the endosome due to increased osmotic pressure, which causes endosomal instability and escape of nucleic acids (Ahmad et al. 2019). In addition, various endosomolytic agents are being tested with materials such as peptides, toxins, polymers, and small molecules (Ahmad et al. 2019). However, cytotoxic effects of these agents significantly limit their applications. Recently, Herrera et al. (2021) have shown that cholesterol substitution in LNPs can enhance endosomal escape of mRNA encoding a galectin8-GFP reporter protein capable of tracking damaged endosomes, supporting the strategy of modifying the structural relationship of components interacting with sterol components.

LNP is a lipid-based carrier composed of lipids, phospholipids (for structure support), cholesterol (stabilizing agents), and polyethylene glycol (PEG)-lipids (increase half-life) (Cullis and Hope 2017). Depending on charge properties of LNP at neutral $\mathrm{pH}$ conditions, LNPs can be classified into three types: ionizable LNPs, cationic LNPs, and neutral LNPs. Ionizable LNPs appears in an uncharged state throughout circulation. However, in low-pH environments such as endosomes and lysosomes, they can be protonated to contribute to endosomal escaping of nucleic acid to the cytoplasm as mentioned above (Ahmad et al. 2019; Hu et al. 2020). Cationic LNPs usually show positive surface charge in circulation. They have immunogenicity or interactions with serum proteins induced by static electricity, resulting less efficiency than ionizable LNP (Hu et al. 2020). Cationic LNPs also show higher in vivo toxicity than ionizable LNPs. As a result, most pharmaceutical companies and institutes are devoting a lot of resources to the development of novel ionizable lipids.

For siRNA, conjugation with a nanocarrier or siRNA with some ligands has been well demonstrated as a good delivery strategy (Osborn and Khvorova 2018; Hu et al. 2020). These conjugated siRNAs can enhance their delivery and cellular uptake, promote targeting due to ligand properties of conjugation molecules, and improve dose efficiency with fewer side effects (Hu et al. 2020). In addition, as compared to LNP, conjugation has the advantage of having smaller size with less toxicity and immunogenicity (Osborn and Khvorova 2018; Hu et al. 2020). N-acetylgalactosamine (GalNAc) sugar is a representative conjugation molecule. Two commercially available siRNA drugs (givosiran and lumasiran) employ this platform. GalNAc has ligand properties for 


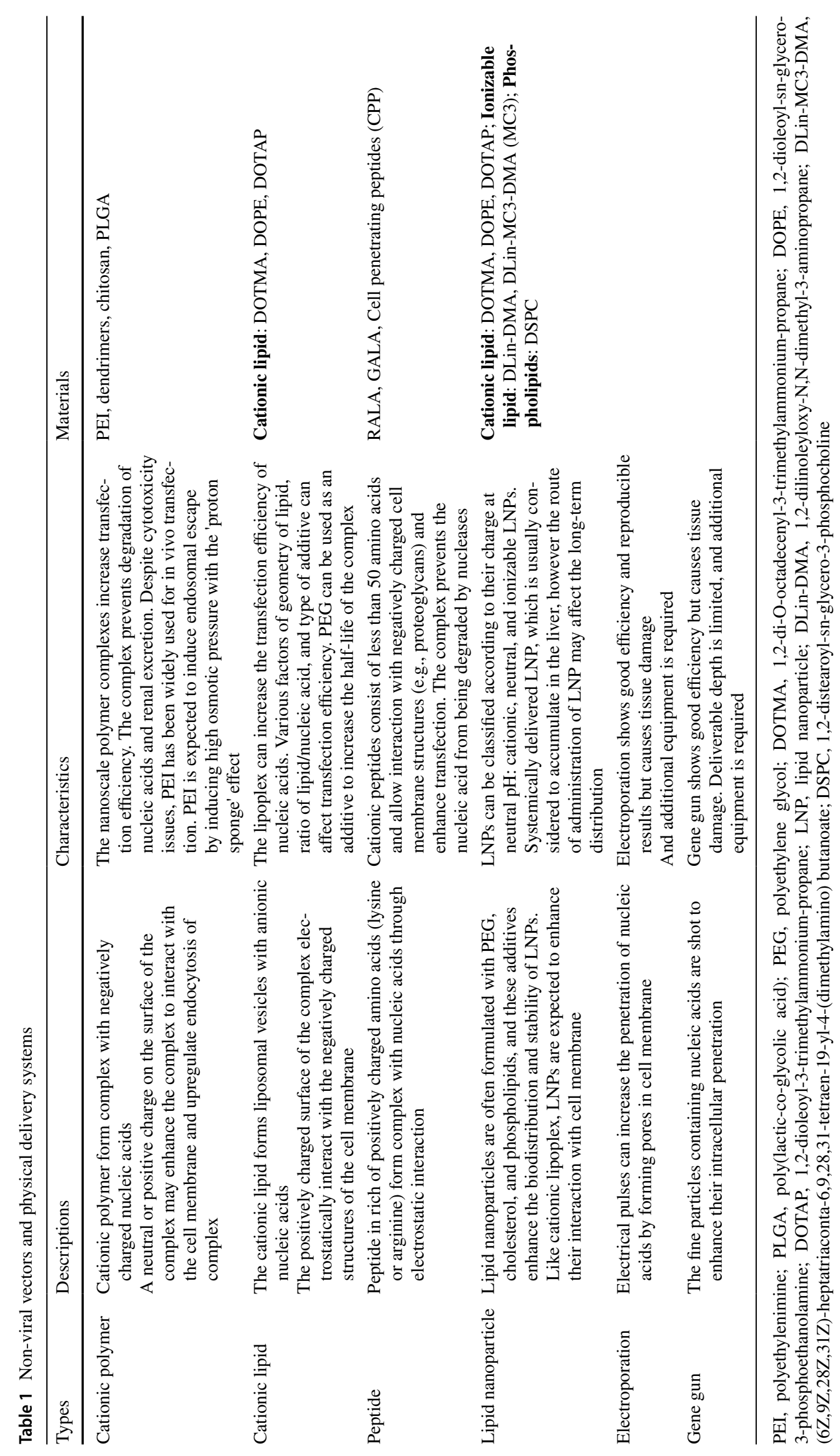


specificity on asialoglycoprotein receptor which is widely distributed in the liver. It has demonstrated an enhanced efficacy with a long half-life, making it an important platform for siRNA delivery (Zhang et al. 2021).

\section{Physical delivery system}

Physical delivery systems of nucleic acids can be classified according to their delivery method which might be direct injection, electroporation, gene gun, or MNs. Although a physical delivery system uses a straightforward delivery process to enhance delivery efficiency by a series of mechanisms, it can show limitations with single utilization itself since it can cause instability related to naked nucleic acid drugs previously discussed or tissue damage which may cause apoptosis of cells (Chen et al. 2016; Pardi et al. 2018). Physical delivery system coupled with a non-viral vector can be used as a possible strategy to deliver nucleic acids into cells more effectively than when either a physical delivery system or a non-viral vector is used alone (Huang et al. 2018).

Physical delivery system using electroporation method can cause electrical pulses to cells or tissue to form pores on their membranes so that nucleic acid drugs can be delivered directly to the cytoplasm, enabling bypass of endosomerelated problems (Pardi et al. 2018; Bernelin-Cottet et al. 2019). Gene gun is a kind of microparticle delivery system with a needle-free method. It takes gene-loaded microparticles to cells/tissues through an accelerator. However, these methods can significantly damage tissues and cause cell death (Chen et al. 2016; Pardi et al. 2018). In addition, they require expensive equipment.

\section{Microneedle system}

The MN system is a one of transdermal drug delivery systems that can promote drug permeation through skin by punching a physical channel through a metal or polymer needle of $1500 \mu \mathrm{m}$ or less on the stratum corneum layer which is considered the largest barrier for transdermal delivery (Kaushik et al. 2001; Arora et al. 2008; Chen et al. 2016). With minimal invasiveness, permeation of nucleic acid drugs such as pDNA and mRNA as well as other macromolecules can be greatly enhanced with less pain (Kim et al. 2013; Yin et al. 2013). This straight method can be applied by selfadministration without a medical expert help, thus increasing user convenience and providing enhanced stability of the nucleic acid drug due to a dried formulation (Pearton et al. 2012; McCaffrey et al. 2016). According to drug loading location and properties as shown in Fig. 1, MN can be divided into four types: solid MN, coated MN, dissolving MN, and hollow MN (Chen et al. 2016). Characteristics of MNs used as nucleic acid delivery systems are described below and summarized in Table 2 .

\section{Solid microneedles}

To enhance drug penetration, solid $\mathrm{MN}$ is composed of metal, silicone, polymer, or ceramic to pierce the skin before or after casting the drug solution on the skin. It is generally manufactured using a dry or wet etch technique (Chabri et al. 2004; Martanto et al. 2004; Birchall et al. 2005). Because solid MN does not contain drugs, administration method using solid MN may be accomplished in two methods: 1) Apply a drug-loaded solution/gel on the skin and then apply the solid MN, 2) Apply solid MNs on the skin and then apply a drug-loaded solution/gel loading. When these two solid MN application methods were compared using a reporter gene encoding plasmid DNA (Yan et al. 2014), the method of applying the microneedle after applying the plasmid solution showed 87 times higher luciferase expression than the method of applying the microneedle before applying the plasmid solution.

Solid MN is expected to have great penetration efficiency since it employs a material like metal or silicon to provide strong mechanical characteristics. However, fine fragments such as a sharp tip may be left as a residue in the skin. Furthermore, the dosage given to the body is significantly lower

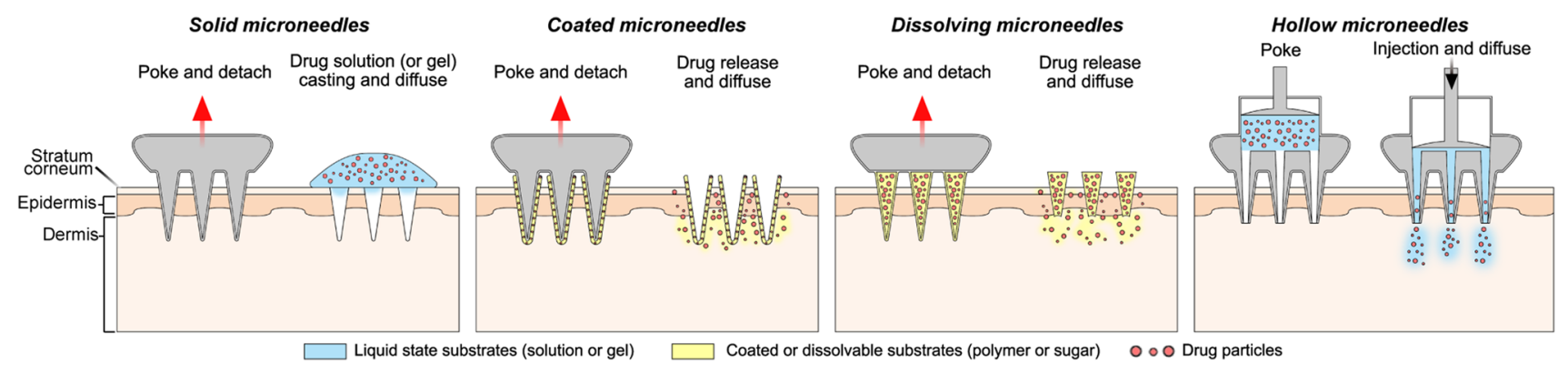

Fig. 1 Types of microneedle systems 


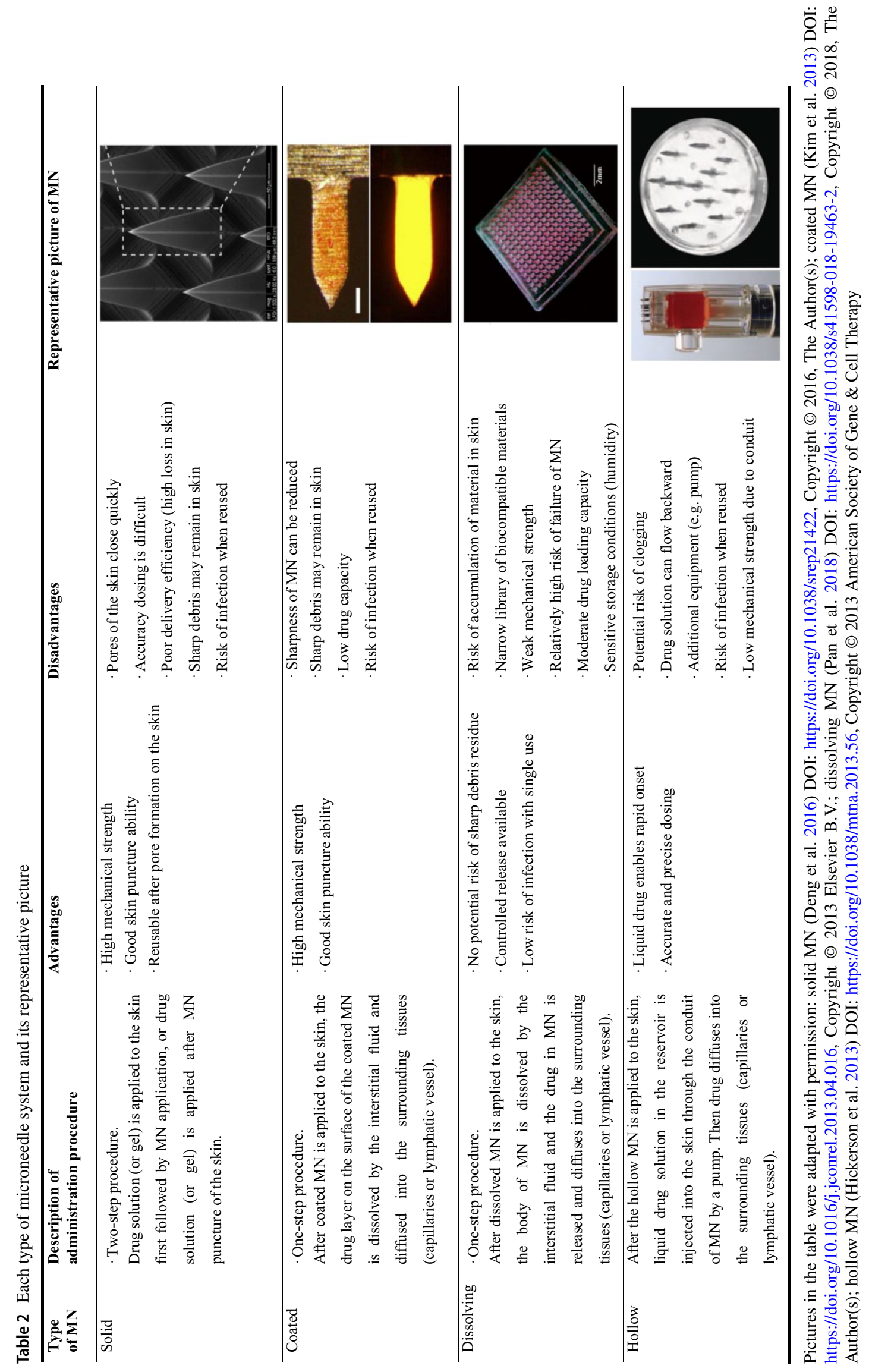


than that of a drug given in a gel/solution form, resulting in huge loss and poor delivery reproducibility.

\section{Coated microneedles}

Coated MN is manufactured by dipping or spraying a solution containing a drug onto the surface of a solid MN (Gill et al. 2010; Li et al. 2021). The drug and polymer vehicle (such as sodium carboxymethylcellulose) on coated MN dissolve quickly after epidermal application, allowing the loaded medication to permeate into neighboring tissues or the bloodstream. Unlike solid MN, coated MN does not require an extra step such as drug solution deposition on skin before or after MN application. In addition, coated MN has less drug loss in the administration procedure than solid $\mathrm{MN}$, and adding a stabilizer such as trehalose can enhance the drug's stability (Pearton et al. 2012; Kim et al. 2013).

Several coating techniques, such as dip coating, inkjet printing, drop coating, or spray coating, for manufacturing coated MN have been demonstrated and characterized in a recent review paper (Ingrole and Gill 2019). The coating height may be changed based on the dipping depth (Gill and Prausnitz 2007). The dose of the nucleic acid might depend on the number of dipping (Pearton et al. 2012). The coating efficiency can be enhanced utilizing a layer-by-layer coating technique and the electrostatic principle (Demuth et al. 2013; Kim et al. 2014; Seok et al. 2017; Duong et al. 2018a; Li et al. $2019 b)$ ). According to a previous report, the number of dipping can increase the dosage of loaded pDNA on the coated MN. It has been confirmed that coated MN array has a content of $100 \mu \mathrm{g}$ (Pearton et al. 2012). However, when manufacturing coated MN with dipping, a high-concentration $(8 \mathrm{mg} / \mathrm{mL})$ of drug solution may need to be prepared (Song et al. 2012), inducing considerable loss or waste by excessive consumption of nucleic acid. In addition, sharp tip pieces of MN components may remain in the skin, as shown in solid MN. Since the $\mathrm{MN}$ and active pharmaceutical ingredients (APIs) are always in contact, the compatibility between the MN material and APIs should also be considered.

\section{Dissolving microneedles}

When applied to the skin, dissolving $\mathrm{MN}$ is rapidly dissolved by the tissue fluid, releasing drug molecules. Dissolving MN is composed of biodegradable polymers or saccharides, containing drug vehicle inside the MN. Because it contains drug molecules, dissolving MN, like coated $\mathrm{MN}$, can be administered in a single step. This can be manufactured using a micro-molding technique or a drawing lithography. The loading dose of dissolving $\mathrm{MN}$ is considered to be greater than that of coated MN (Chen et al. 2016). In addition, accurate and flexible dose adjustment is possible. There is no concern about the sharp tip of metal $\mathrm{MN}$ remaining in the skin. Because release properties of drugs from dissolving $\mathrm{MN}$ are greatly affected by the composition of polymers and additives, its therapeutic efficacy could be enhanced by controlling release properties of dissolved MN. However, the mechanical strength of the dissolving $\mathrm{MN}$ must be sufficient enough to penetrate the skin. In addition, dissolving $\mathrm{MN}$ is sensitive to storage conditions owing to moisture, which might affect its mechanical strength. It is also critical to consider degradation of the polymer that is absorbed into the body and biocompatibility of biodegradable polymers as these aspects can severely limit the range of materials. Waste of drugs in the manufacturing process, such as sidewalls of MNs and the baseplate part of MN considered less bioavailable than the needle tip itself appears to be considerable (approximately $50 \%$ of drugs are discarded after manufacturing) (Cole et al. 2017). Thus, a manufacturing process using a micro-molding system should be developed to minimize such drug loss.

\section{Hollow microneedles}

A hollow $\mathrm{MN}$ is often a $\mathrm{MN}$ into which a liquid drug from the reservoir located underside of $\mathrm{MN}$ is delivered via a needle tube or an opened channel (Hickerson et al. 2013). The flow rate and pressure are generally controlled by a separate device (Mansoor et al. 2015; Bae et al. 2019; Cárcamo-Martínez et al. 2021). A comparatively large amount of drug can be delivered precisely with a hollow MN than with other types of MN. However, exceeding the threshold pressure or flow rate may induce backflow through the side wall around the needle (Mansoor et al. 2015). Therefore, it needs to be delivered with a suitable pressure and speed, this limiting the delivery rate. A flow rate of $200 \mathrm{~nL} / \mathrm{min}$ used as a reference appears to be inefficient (Mansoor et al. 2015). Furthermore, because the drug is delivered in a liquid form, the stability of the drug may cause a problem compared to coated or dissolving MNs with a dry condition for encapsulated drugs (Cárcamo-Martínez et al. 2021). Using a biomimetic construction, Bae et al. (2019) have created an open channel MN. Using microfluidics, a snake fang MN could spontaneously inject drug solutions from drug reservoirs into the skin (Bae et al. 2019).

\section{Microneedles for nucleic acid delivery}

Many studies have proven the efficacy of nucleic acid drug delivery systems using various types of MNs (Table 3). Figure 2 shows schematic configurations of several types of $\mathrm{MN}$ systems and physical delivery systems combined with $\mathrm{MN}$ for nucleic acid drug delivery. Many of them have focused on nucleic acid vaccine for cancer/infectious diseases. Several investigations have compared the effectiveness of $\mathrm{MN}$ 
systems for nucleic acid drug delivery to other delivery routes by adopting reporter gene encoding or reporter gene silencing nucleic acids (González-González et al. 2011; Demuth et al. 2013; Dul et al. 2017; Liang et al. 2020; Liu et al. 2021). A MN system coupled with well-designed nonviral vectors, or a physical delivery method often exceeds the $\mathrm{MN}$ alone with naked nucleic acid delivery. This section discusses recent advances in $\mathrm{MN}$-based nucleic acid vaccination for infectious diseases or cancer. Furthermore, we highlighted research on the effects of MN morphology or formulation on the efficacy of nucleic acid-encapsulated MNs. In addition, studies on MN combined with other nucleic acid delivery systems are described. Finally, limitations and considerations for developing MNs for nucleic acid delivery are discussed.

\section{MN-based nucleic acid vaccination}

Because of the abundance of immune cells in the skin, conventional antigen vaccines and nucleic acid vaccines can successfully elicit an immune response with an $\mathrm{MN}$ system. Prow et al. (2010) have visualized MN-induced migration of thousands of antigen presenting cells (APCs) in epidermal area of mice after activating with a conventional antigen or DNA vaccine through $\mathrm{MN}$ application (Prow et al. 2010). In addition to serving as a delivery system, MN system may serve as a physical adjuvant by increasing cell death-induced immunity during application (Depelsenaire et al. 2014; Takeuchi et al. 2016). Furthermore, because of its benefits of stability and simplicity, using $\mathrm{MN}$ is considered as a practical and efficient method for nucleic acid vaccination.

Compared to traditional delivery methods such as intramuscular (IM) or subcutaneous (SC) injection, MNbased nucleic acid vaccines can produce efficient immune responses (Gill et al. 2010; Kim et al. 2012; Song et al. 2012; Ma et al. 2014; Fernando et al. 2016; Yang et al. 2017; Liao et al. 2017; Moreno et al. 2017; Duong et al. 2018b, 2020; Zhang et al. 2018; Yan et al. 2018). Song et al. (2012) have demonstrated that naked influenza hematogglutinin (HA)encoding plasmid DNA coated onto metal MN has protective effect. Furthermore, the dose utilizing MN system may be reduced more than five times when compared to IM. Yang et al. (2017) have reported that the thermostability of pDNA vaccine using a dissolving MN system for six weeks by encapsulating pDNA vaccine against Ebola virus with poly(lactic-co-glycolic acid) based nanoparticles carrier is enhanced. The pDNA MN for Ebola virus demonstrated higher IgG titer than an IM route, showing the efficacy of Ebola immunization using MN-based pDNA vaccine. In another research, Liao et al. (2017) have fabricated a dissolving MN vaccine utilizing a pDNA polyplex coupled with cationic branched PEI (polyethylenimine), which is 3.5 times more efficient than IM.

The effectiveness and potentials of nucleic acid based cancer vaccines using MN system by loading tumor-associated antigen-encoding mRNA, pDNA, or siRNA which interferes with mRNA encoding tumor associated protein into MN have been demonstrated (Hooper et al. 2007; Prow et al. 2010; Gill et al. 2010; Song et al. 2012; Kim et al. 2012, 2014; Ma et al. 2014; Kines et al. 2015; Fernando et al. 2016; Ali et al. 2017; Pamornpathomkul et al. 2017; Xu et al. 2017; Cole et al. 2018, 2019; Koh et al. 2018; Pan et al. 2018; Ruan et al. 2018; Duong et al. 2018b, 2020; Li et al. 2019b). Cole et al. (2019) have utilized a prostate stem cell antigen (PSCA) encoding pDNA with dissolving MN using RALA peptide (one of the cell penetrating peptides) nanoparticle carrier to establish prophylactic and therapeutic efficacy. Li et al. (2019a) have generated pH-triggered release to promote rapid release at a relatively low $\mathrm{pH}$ (5.5) by coating PEI and p53-encoding pDNA on a pH-responsive poly-electrolyte multilayer (PEM), confirming its tumor suppression ability.

Several research studies have used adjuvants with MNbased nucleic acid vaccinations (Zhou et al. 2010; Qiu et al. 2016; Xu et al. 2017; Duong et al. 2018b, 2020). Adjuvants can boost the vaccination effectiveness by inducing additional immunological response. Adjuvants such as poly I:C (Duong et al. 2018b, 2020) and paclitaxel (Xu et al. 2017) have been used in some cases for MN-based cancer vaccines. It has been demonstrated that the immunogenicity of $\mathrm{MN}$ based vaccine is improved in the group with adjuvant added.

In one work, photothermal therapy with IR820 NIR dye has been used in a hyaluronic acid based dissolving $\mathrm{MN}$ encapsulating p53-encoding pDNA. This complexed system substantially suppressed the growth of melanoma (Xu et al. 2020).

\section{Effect of morphology and formulation of microneedle}

Since MNs operate by physically punching a hole in the stratum corneum, mechanical strength and morphology known to directly impact penetration properties of $\mathrm{MN}$ are critical for efficient delivery. Solid MN and coated $\mathrm{MN}$ are largely free of these issues in terms of mechanical strength because these MNs are composed of strong enough materials such as metals. Nevertheless, mechanical strength is an essential factor for dissolving $\mathrm{MN}$ which is made of polymer or sugar. Mechanical strength of dissolving $\mathrm{MN}$ can be influenced by formulation, storage conditions such as humidity, and structure (Wang et al. 2018). Dissolving MNs fabricated with four other biocompatible polymers (hyaluronate, chitosan, gelatin, or polyvinyl alcohol) were evaluated in this study. The findings 
Table 3 Features and findings of research on microneedle system for nucleic acid drug delivery

\begin{tabular}{|c|c|c|c|c|c|}
\hline Type of MN & $\begin{array}{l}\text { Combined deliv- } \\
\text { ery system }\end{array}$ & Applications & $\begin{array}{l}\text { Target nucleic } \\
\text { acid }\end{array}$ & Features and findings & References \\
\hline Solid & Non (naked) & $\begin{array}{l}\text { Gene expression, } \\
\text { Cancer vaccine }\end{array}$ & $\begin{array}{l}\text { HBsAg pDNA } \\
\text { Luciferase pDNA }\end{array}$ & $\begin{array}{l}\text { Adjuvant (Flt3L, Fms-like } \\
\text { tyrosine kinase } 3 \text { ligand) was } \\
\text { added } \\
\text { Immune response: MN + adju- } \\
\text { vant }+ \text { pDNA }>\text { IM + adjuvant } \\
\text { pDNA } \sim \mathrm{MN}+\text { pDNA } \\
\text { Protective efficacy against } \\
\text { tumor cell challenge was } \\
\text { observed in mice }\end{array}$ & Zhou et al. (2010) \\
\hline Solid & Non (naked) & Gene knockdown & GAPDH siRNA & $\begin{array}{l}5 \text { ' cholesterol modification was } \\
\text { introduced into siRNA to } \\
\text { enhance cellular uptake } \\
\text { Evaluation of in vivo biodis- } \\
\text { tribution of Cy5-labelled } \\
\text { siRNA was included } \\
\text { (Major distribution in MN- } \\
\text { applied tissues compared to } \\
\text { major organs) }\end{array}$ & Deng et al. (2016) \\
\hline Solid hollow & $\begin{array}{l}\text { Non (Naked), } \\
\text { Electroporation, } \\
\text { Cationic poly- } \\
\text { mer/lipid }\end{array}$ & $\begin{array}{l}\text { Immunization } \\
\text { study }\end{array}$ & Ovalbumin pDNA & $\begin{array}{l}\text { Permeability of DNA have } \\
\text { been compared between EP, } \\
\text { SC, solid MN, EP + solid } \\
\text { MN, and hollow MN (33- } \\
\text { gauge hypodermic nee- } \\
\text { dle). Characterization and } \\
\text { optimization of complexes } \\
\text { using commercial transfec- } \\
\text { tion reagents (Lipofectamine, } \\
\text { Superfect) and cationic } \\
\text { polymer (PEI). Hollow } \\
\text { MN showed a much higher } \\
\text { immune response than SC } \\
\text { injection. The complex } \\
\text { elicited a stronger immune } \\
\text { response than the naked, } \\
\text { with the strongest response } \\
\text { in PEI complex }\end{array}$ & Pamornpathomkul et al. (2017) \\
\hline Solid & $\begin{array}{l}\text { Non (naked), } \\
\text { Cationic poly- } \\
\text { mer/lipid }\end{array}$ & Gene expression & $\begin{array}{l}\text { Luciferase pDNA } \\
\text { EGFP pDNA }\end{array}$ & $\begin{array}{l}\text { Longer MN and longer dura- } \\
\text { tion time showed stronger } \\
\text { expression than shorter one. } \\
\text { And naked DNA showed } \\
\text { better expression than com- } \\
\text { plexed one } \\
\text { DNA } \rightarrow \text { MN showed 87-times } \\
\text { higher expression than } \\
\text { MN } \rightarrow \text { DNA }\end{array}$ & Yan et al. (2014) \\
\hline Solid & $\begin{array}{l}\text { Cationic polymer } \\
\text { (PEI) }\end{array}$ & $\begin{array}{l}\text { Gene expression, } \\
\text { Immunization } \\
\text { study }\end{array}$ & $\begin{array}{l}\text { Luciferase pDNA } \\
\text { Hepatitis B } \\
\text { HBsAg pDNA }\end{array}$ & $\begin{array}{l}\text { IM (naked) vs. MN (naked) } \\
\text { vs. IM (complex) vs. MN } \\
\text { (complex) } \\
\text { PEI-pDNA loaded MN showed } \\
\text { a 4.7-fold higher immune } \\
\text { response than IM injec- } \\
\text { tion and a 2.6-fold higher } \\
\text { immune response than naked } \\
\text { DNA loaded MN }\end{array}$ & Yin et al. (2013) \\
\hline
\end{tabular}


Table 3 (continued)

\begin{tabular}{|c|c|c|c|c|c|c|}
\hline Type of MN & $\begin{array}{l}\text { Combined deliv- } \\
\text { ery system }\end{array}$ & Applications & $\begin{array}{l}\text { Target nucleic } \\
\text { acid }\end{array}$ & Features and findings & \multicolumn{2}{|l|}{ References } \\
\hline Solid & $\begin{array}{l}\text { Cationic poly- } \\
\text { mer- } \\
\text { cell penetrating } \\
\text { peptide }\end{array}$ & Gene expression & $\begin{array}{l}\text { Luciferase pDNA } \\
\text { EGFP pDNA }\end{array}$ & $\begin{array}{l}\text { Mannosylated PEI-CPP-pDNA } \\
\text { complexes targeting mannose } \\
\text { receptor positive dendritic } \\
\text { cells. The complex exhibited } \\
150 \text {-fold higher expression } \\
\text { than naked pDNA in vitro } \\
\text { expression study }\end{array}$ & \multicolumn{2}{|l|}{ Hu et al. (2014) } \\
\hline Solid & $\begin{array}{l}\text { Cationic lipo- } \\
\text { some } \\
\text { (DOTAP) }\end{array}$ & Gene knockdown & GAPDH siRNA & $\begin{array}{l}\text { Utilization of sponge Hali- } \\
\text { clona sp. Spicules as solid } \\
\text { MN. Liposome-siRNA } \\
\text { complex } \\
\text { \% Knockdown: MN + com- } \\
\text { plex > SC + com- } \\
\text { plex > MN + siRNA }\end{array}$ & \multicolumn{2}{|c|}{ Liang et al. (2020) } \\
\hline Solid & $\begin{array}{l}\text { Lipid nanopar- } \\
\text { ticle } \\
\text { (DOTAP) }\end{array}$ & Gene expression & $\begin{array}{l}\text { EGFP pDNA } \\
\beta \text {-galactosidase } \\
\text { pDNA }\end{array}$ & $\begin{array}{l}\text { In vitro transfection efficiency } \\
\text { and in vitro permeation study } \\
\text { were involved } \\
\text { DOTAP based lipid nanoparti- } \\
\text { cle were tested with different } \\
\text { charge condition (positive, } \\
\text { neutral, negative). Positive } \\
\text { charged nanoparticle only } \\
\text { showed expression }\end{array}$ & \multicolumn{2}{|c|}{$\begin{array}{l}\text { Chabri et al. (2004) and Coul- } \\
\text { man et al. (2005) }\end{array}$} \\
\hline Solid & Electroporation & $\begin{array}{l}\text { Gene expression, } \\
\text { Fluorescently } \\
\text { labelled RNA } \\
\text { transfection }\end{array}$ & $\begin{array}{l}\text { RFP pDNA, } \\
\text { Cy5 labelled } \\
\text { siRNA }\end{array}$ & $\begin{array}{l}\text { Gold coated solid MN used for } \\
\text { electroporation. Transfection } \\
\text { efficiency and tissue damage } \\
\text { were evaluated at various } \\
\text { voltages (range } 0-50 \mathrm{~V} \text { ) } \\
\text { for the combination of MN } \\
\text { and electroporation. MN } \\
\text { alleviated the EP condi- } \\
\text { tions, allowing it to decrease } \\
\text { to } 35 \mathrm{~V} \text { with maximum } \\
\text { transfection efficiency. MN } \\
\text { combined with electropora- } \\
\text { tion enhanced transfection } \\
\text { of nucleic acids. Roller type } \\
\text { MN was utilized to enhance } \\
\text { transfection efficiency. } \\
\text { Longer MN showed better } \\
\text { expression }\end{array}$ & \multicolumn{2}{|c|}{$\begin{array}{l}\text { Wei et al. (2014) and Huang } \\
\text { et al. (2018) }\end{array}$} \\
\hline Coated & Non (naked) & $\begin{array}{l}\text { Gene expression, } \\
\text { Immunization } \\
\text { study }\end{array}$ & $\begin{array}{l}\text { Luciferase pDNA, } \\
\text { Gag encoding } \\
\text { pDNA } \\
\text { (HIV model anti- } \\
\text { gen SIV-gag) }\end{array}$ & \multicolumn{2}{|c|}{$\begin{array}{l}\text { Multilayer coated MN enabling rapid release } \\
\text { of pDNA in pH-responsive manner. PolyI:C } \\
\text { was used for adjuvant. 140-fold higher level of } \\
\text { expression with MN compared to ID injec- } \\
\text { tion (reporter gene). The dried formulation } \\
\text { maintained the bioactivity of pDNA for } 28 \text { days } \\
\text { at room temperature. tenfold higher antibody } \\
\text { titers with MN compared to other treatments } \\
\text { (ID, IM, IM+EP) }\end{array}$} & $\begin{array}{l}\text { Demuth et al. } \\
\text { (2013) }\end{array}$ \\
\hline Coated & Non (naked) & Cancer vaccine & $\begin{array}{l}\text { Hepatitis } \mathrm{C} \text { virus } \\
\text { 3/4A pDNA }\end{array}$ & \multicolumn{2}{|c|}{$\begin{array}{l}\text { MN had an immune response similar to that of } \\
\text { the gene gun at similar doses. MN }(3.2 \mu \mathrm{g}) \\
\text { showed protective efficacy in tumor cell chal- } \\
\text { lenge and equivalent immune response to a } \\
\text { 30-fold higher dose of IM }(100 \mu \mathrm{g})\end{array}$} & $\begin{array}{l}\text { Gill et al. } \\
\text { (2010) }\end{array}$ \\
\hline
\end{tabular}


Table 3 (continued)

\begin{tabular}{|c|c|c|c|c|c|}
\hline Type of MN & $\begin{array}{l}\text { Combined deliv- } \\
\text { ery system }\end{array}$ & Applications & $\begin{array}{l}\text { Target nucleic } \\
\text { acid }\end{array}$ & Features and findings & \\
\hline Coated & Non (naked) & $\begin{array}{l}\text { Gene expression, } \\
\text { Immunization } \\
\text { study }\end{array}$ & $\begin{array}{l}\text { Luciferase pDNA } \\
\text { Influenza HA } \\
\text { pDNA }\end{array}$ & $\begin{array}{l}\text { Coated MN showed protective efficacy on viral } \\
\text { challenge and improved immune response com- } \\
\text { pared to the same dose of IM. Immunization } \\
\text { study using clodronate-liposomes suggest that } \\
\text { dendritic and macrophages may not provide a } \\
\text { major contribution to protective efficacy of MN }\end{array}$ & $\begin{array}{l}\text { Song et al. } \\
\text { (2012) and } \\
\text { Kim et al. } \\
(2013)\end{array}$ \\
\hline Coated & Non (naked) & $\begin{array}{l}\text { Immunization } \\
\text { study }\end{array}$ & $\begin{array}{l}\text { Nucleosomal } \\
\text { histones of } \\
\text { Leishmania spp } \\
\text { pDNA }\end{array}$ & $\begin{array}{l}\text { Comparison of immune responses by adminis- } \\
\text { tration route of pDNA cocktails of plasmids } \\
\text { encoding four different antigens. Immune } \\
\text { response: } \mathrm{SC}<\mathrm{ID}<\mathrm{MN}\end{array}$ & $\begin{array}{l}\text { Moreno et al. } \\
\text { (2017) }\end{array}$ \\
\hline Coated & Non (naked) & $\begin{array}{l}\text { Gene expression, } \\
\text { Immunization } \\
\text { study }\end{array}$ & $\begin{array}{l}\text { EGFP pDNA } \\
\text { Ovalbumin pDNA }\end{array}$ & $\begin{array}{l}\text { MN showed a tenfold higher immune response } \\
\text { compared to IM injection. Gene expression and } \\
\text { immune response: } \mathrm{IM}<\mathrm{MN}\end{array}$ & $\begin{array}{l}\text { Zhang et al. } \\
\text { (2018) }\end{array}$ \\
\hline Coated & $\begin{array}{l}\text { Cationic polymer } \\
\text { (PEI) }\end{array}$ & Cancer vaccine & p53 pDNA & $\begin{array}{l}\text { PEI-pDNA complex coated on polycaprolactone } \\
\text { MN by layer-by-layer assembly. pH-responsive } \\
\text { pDNA release promoted in the acidic environ- } \\
\text { ment (pH 5.5). pH responsive MNs showed } \\
\text { better tumor suppression than non-multilayered } \\
\text { MNs or IV injections }\end{array}$ & $\begin{array}{l}\text { Li et al. } \\
\quad(2019 b)\end{array}$ \\
\hline Coated & $\begin{array}{l}\text { Cationic lipo- } \\
\text { some } \\
\text { (DOTAP) }\end{array}$ & Gene knockdown & $\begin{array}{l}\text { CXCL1 gene } \\
\text { siRNA }\end{array}$ & $\begin{array}{l}\text { The nano-patch was coated with DOTAP-PEG- } \\
\text { cholesterol-siRNA complex and methylcellu- } \\
\text { lose for viscosity improving agent. Fluvax (one } \\
\text { of the vaccines) was added to induce CXCL1 } \\
\text { expression. The integrity of nucleic acid was } \\
\text { maintained in the dry state }\end{array}$ & $\begin{array}{l}\text { Haigh et al. } \\
\text { (2014) }\end{array}$ \\
\hline Coated & $\begin{array}{l}\text { Nanoparticle } \\
\text { (PEI-deoxycho- } \\
\text { late) }\end{array}$ & $\begin{array}{l}\text { Gene expression, } \\
\text { Immunization } \\
\text { study }\end{array}$ & $\begin{array}{l}\text { Alzheimer beta- } \\
\text { amyloid pDNA }\end{array}$ & $\begin{array}{l}\text { Multilayer MN enhanced rapid release at physi- } \\
\text { ological pH. Mannosylated PEI-deoxycholic } \\
\text { acid-pDNA complexes were treated with SC } \\
\text { or MN. MN showed a higher immune response } \\
\text { compared to the SC group. Trehalose was used } \\
\text { as a stabilizing agent }\end{array}$ & $\begin{array}{l}\text { Kim et al. } \\
\text { (2014) and } \\
\text { Duong et al. } \\
\text { (2018a) }\end{array}$ \\
\hline Coated & $\begin{array}{l}\text { Nanoparticle } \\
\text { (PEI-deoxy- } \\
\text { cholic acid) }\end{array}$ & $\begin{array}{l}\text { Cancer vaccine } \\
\text { (melanoma) }\end{array}$ & Ovalbumin pDNA & $\begin{array}{l}\text { Rapid release at physiological } \mathrm{pH} \text { was induced } \\
\text { with a multilayer } \mathrm{MN} \text { (pH-responsive layer). } \\
\text { Poly I:C was co-administered as an adjuvant }\end{array}$ & $\begin{array}{l}\text { Duong et al. } \\
\text { (2018b) }\end{array}$ \\
\hline Dissolving & Non (naked) & $\begin{array}{l}\text { Gene expression, } \\
\text { Cancer vaccine }\end{array}$ & $\begin{array}{l}\text { Luciferase mRNA } \\
\text { Ovalbumin } \\
\text { mRNA }\end{array}$ & $\begin{array}{l}\text { Naked mRNA was loaded into PVP-based dis- } \\
\text { solving MN. The concentrated PVP solution } \\
\text { lowered the in vivo transfection efficiency of } \\
\text { mRNA in PVP solution } \\
\text { Longer MNs showed higher mRNA expression } \\
\text { in vivo }\end{array}$ & $\begin{array}{l}\text { Koh et al. } \\
\text { (2018) }\end{array}$ \\
\hline Dissolving & $\begin{array}{l}\text { Nanoparticle } \\
\text { (PLGA-based) }\end{array}$ & $\begin{array}{l}\text { Gene expression, } \\
\text { Immunization } \\
\text { study }\end{array}$ & $\begin{array}{l}\text { GFP pDNA } \\
\text { Ebolavirus pro- } \\
\text { tein pDNA }\end{array}$ & $\begin{array}{l}\text { The PLGA-Poly(L-lysine)-poly( } \gamma \text {-glutamate)- } \\
\text { DNA complex was loaded onto PVA-based dis- } \\
\text { solving MN. Sucrose stabilized pDNA structure } \\
\text { of MN at room temperature } \\
\text { Immune response: } \mathrm{MN}+\mathrm{NP}+\mathrm{pDNA}>\mathrm{IM}+\mathrm{NP} \\
+ \text { pDNA }>\mathrm{IM}+\mathrm{pDNA}>\mathrm{MN}+\mathrm{pDNA}\end{array}$ & $\begin{array}{l}\text { Yang et al. } \\
\text { (2017) }\end{array}$ \\
\hline Dissolving & $\begin{array}{l}\text { Cationic polymer } \\
\text { (PEI) }\end{array}$ & $\begin{array}{l}\text { Cancer vaccine } \\
\text { (melanoma) }\end{array}$ & STAT3 siRNA & $\begin{array}{l}\text { PEI-siRNA complex loaded into dissolving } \\
\text { MN (matrix composition: dextran40: PVP17: } \\
\text { HA =4:1:1). Naked siRNA showed lower } \\
\text { transfection than complex siRNA (in vitro). } \\
\text { Dose dependence was confirmed with four dose } \\
\text { levels }(33,66,132 \text {, and } 264 \mu \mathrm{g} \text { ) }\end{array}$ & $\begin{array}{c}\text { Pan et al. } \\
\text { (2018) }\end{array}$ \\
\hline
\end{tabular}


Table 3 (continued)

\begin{tabular}{|c|c|c|c|c|c|}
\hline Type of MN & $\begin{array}{l}\text { Combined deliv- } \\
\text { ery system }\end{array}$ & Applications & $\begin{array}{l}\text { Target nucleic } \\
\text { acid }\end{array}$ & Features and findings & \\
\hline Dissolving & $\begin{array}{l}\text { Peptide nanopar- } \\
\text { ticle }\end{array}$ & $\begin{array}{l}\text { Gene expression, } \\
\text { Cancer vaccine }\end{array}$ & $\begin{array}{l}\text { Luciferase pDNA } \\
\text { HPV-16 E6 and } \\
\text { E7 pDNA }\end{array}$ & $\begin{array}{l}\text { RALA (one of cell penetrating peptide)-pDNA } \\
\text { complex loaded into PVA-based dissolving } \\
\text { MN. Lyophilization was used to increase the } \\
\text { loading capacity, and trehalose was used as a } \\
\text { stabilizer for the process. } 57 \mu \text { g of pDNA was } \\
\text { loaded into the array. pDNA loaded in MN } \\
\text { was stable for } 28 \text { days at room temperature. } \\
\text { Complex-MN group showed higher immune } \\
\text { response than complex-IM }\end{array}$ & $\begin{array}{l}\text { Cole et al. } \\
\text { (2018) }\end{array}$ \\
\hline Dissolving & Electroporation & $\begin{array}{l}\text { Gene expression, } \\
\text { Cancer vaccine } \\
\text { (melanoma) }\end{array}$ & $\begin{array}{l}\text { Luciferase pDNA } \\
\text { 2CMVmIL-12 } \\
\text { pDNA (IL-12 } \\
\text { subunits) }\end{array}$ & $\begin{array}{l}\text { Maltose-based dissolved MNs mounted on metal } \\
\text { electrodes array. EP enhanced the expression } \\
\text { of IL-12. pDNA delivery via dissolving MN } \\
\text { combined with electroporation inhibited tumor } \\
\text { growth and extended survival }\end{array}$ & $\begin{array}{l}\text { Lee et al. } \\
\quad(2011)\end{array}$ \\
\hline Dissolving & $\begin{array}{l}\text { Photothermal } \\
\text { therapy }\end{array}$ & $\begin{array}{l}\text { Cancer vaccine } \\
\text { (melanoma) }\end{array}$ & p53 pDNA & $\begin{array}{l}\text { Photothermal dye (named IR 820) and pDNA } \\
\text { were loaded into hyaluronic acid-based dissolv- } \\
\text { ing MN. Near-infrared rays increase the tem- } \\
\text { perature of the tissues where IR820 is distrib- } \\
\text { uted and have anticancer effects. Combination } \\
\text { with photothermal therapy (PTT) effectively } \\
\text { inhibited the growth of subcutaneous tumors }\end{array}$ & $\begin{array}{r}\text { Xu et al. } \\
\text { (2020) }\end{array}$ \\
\hline Hollow & $\begin{array}{l}\text { Cationic } \\
\text { lipid (Lipo- } \\
\text { fectamine) }\end{array}$ & Gene knockdown & $\begin{array}{l}\beta \text {-galactosidase } \\
\text { pDNA EGFP } \\
\text { pDNA }\end{array}$ & $\begin{array}{l}\text { A commercial hollow MN device (MicronJet) } \\
\text { was used, enabling reproducible amounts of } \\
\text { siRNA. Transfection studies using ex vivo } \\
\text { human skin }\end{array}$ & $\begin{array}{l}\text { Dul et al. } \\
\text { (2017) }\end{array}$ \\
\hline Hollow & $\begin{array}{l}\text { Cationic } \\
\text { lipid (Lipo- } \\
\text { fectamine) }\end{array}$ & Gene expression & Luciferase mRNA & $\begin{array}{l}\text { A commercial hollow MN device (MicronJet) } \\
\text { was used. Transfection studies using ex vivo } \\
\text { porcine skin. There were no significant differ- } \\
\text { ences in luciferase expression between naked } \\
\text { mRNA and liposome complexed mRNA }\end{array}$ & $\begin{array}{l}\text { Golombek } \\
\text { et al. (2018) }\end{array}$ \\
\hline Hollow & $\begin{array}{l}\text { Cationic nio- } \\
\text { some }\end{array}$ & $\begin{array}{l}\text { Gene expression, } \\
\text { Immunization } \\
\text { study }\end{array}$ & $\begin{array}{l}\text { EGFP pDNA } \\
\text { Ovalbumin pDNA }\end{array}$ & $\begin{array}{l}\text { Cationic niosome-pDNA complex (composition: } \\
\text { span20/cholesterol/cationic lipids }=2.5 / 2.5 / 0.5 \\
\text { in molar ratio) was delivered in vivo by hollow } \\
\text { MNs. MN injection of niosome complexes } \\
\text { showed a higher immune response than SC } \\
\text { injection } \\
\text { In vivo immune response: Niosome com- } \\
\text { plex }>\text { Lipofectamine complex }>\text { Naked pDNA }\end{array}$ & $\begin{array}{l}\text { Pamornpath- } \\
\text { omkul et al. } \\
\text { (2018) }\end{array}$ \\
\hline
\end{tabular}

$M N$ microneedle, $H B s A g$ hepatitis B surface antigen, $G A P D H$ glyceraldehyde-3-phosphate dehydrogenase, $E P$ electroporation, $S C$ subcutaneous, $P E I$ polyethyleneimine, EGFP enhanced green fluorescent protein, $I M$ intramuscular, $C P P$ cell penetrating peptide, DOTAP 2, 3-dioleoyloxy-propyl-trimethylammoniumchlorid, $R F P$ red fluorescent protein

$M N$ microneedle, $H I V$ human immunodeficiency virus, SIV simian immunodeficiency virus, $I D$ intradermal, $I M$ intramuscular, $E P$ electroporation, $H A$ hemagglutinin, $S C$ subcutaneous, EGFP enhanced green fluorescent protein, $P E I$ polyethyleneimine, $I V$ intravenous, DOTAP 2, 3-dioleoyloxy-propyl-trimethylammoniumchlorid, $C X C L 1$, C-X-C motif chemokine ligand 1, PEG polyethylene glycol

$M N$ microneedle, $P V P$ polyvinylpyrrolidone, $P L G A$ poly(lactide-co-glycolide), $P V A$ polyvinyl alcohol, GFP green fluorescent protein, $N P$ nanoparticle, IM intramuscular, $P E I$ polyethyleneimine, STAT3 signal transducer and activity of transcription $3, H A$ hyaluronic acid, $H P V$ human papillomavirus, EP, CMV, cytomegalovirus, $I L$ interleukin, $E P$ electroporation, $E G F P$ enhanced green fluorescent protein, $S C$ subcutaneous

suggest that mechanical strength and in vivo mouse skin insertion ability may differ significantly depending on the MN material under high humidity conditions, emphasizing the importance of formulation and optimal storage conditions for reproducible administration of dissolving MNs. In addition, morphological characteristics have substantial impacts on $\mathrm{MN}$ penetration regardless of the needle type (Gittard et al. 2013). It has been shown that morphological characteristics such as needle length are critical as they may impact transfection efficiency in nucleic acid delivery (Yan et al. 2014; Koh et al. 2018; Wang et al. 2020). Transfection efficiency and kinetics of naked mRNA depending on needle height have been demonstrated. The longer MNs encapsulating the naked mRNA encoding luciferase (one of the reporter genes) demonstrated better transfection efficiency with a longer duration than the shorter MNs in the 


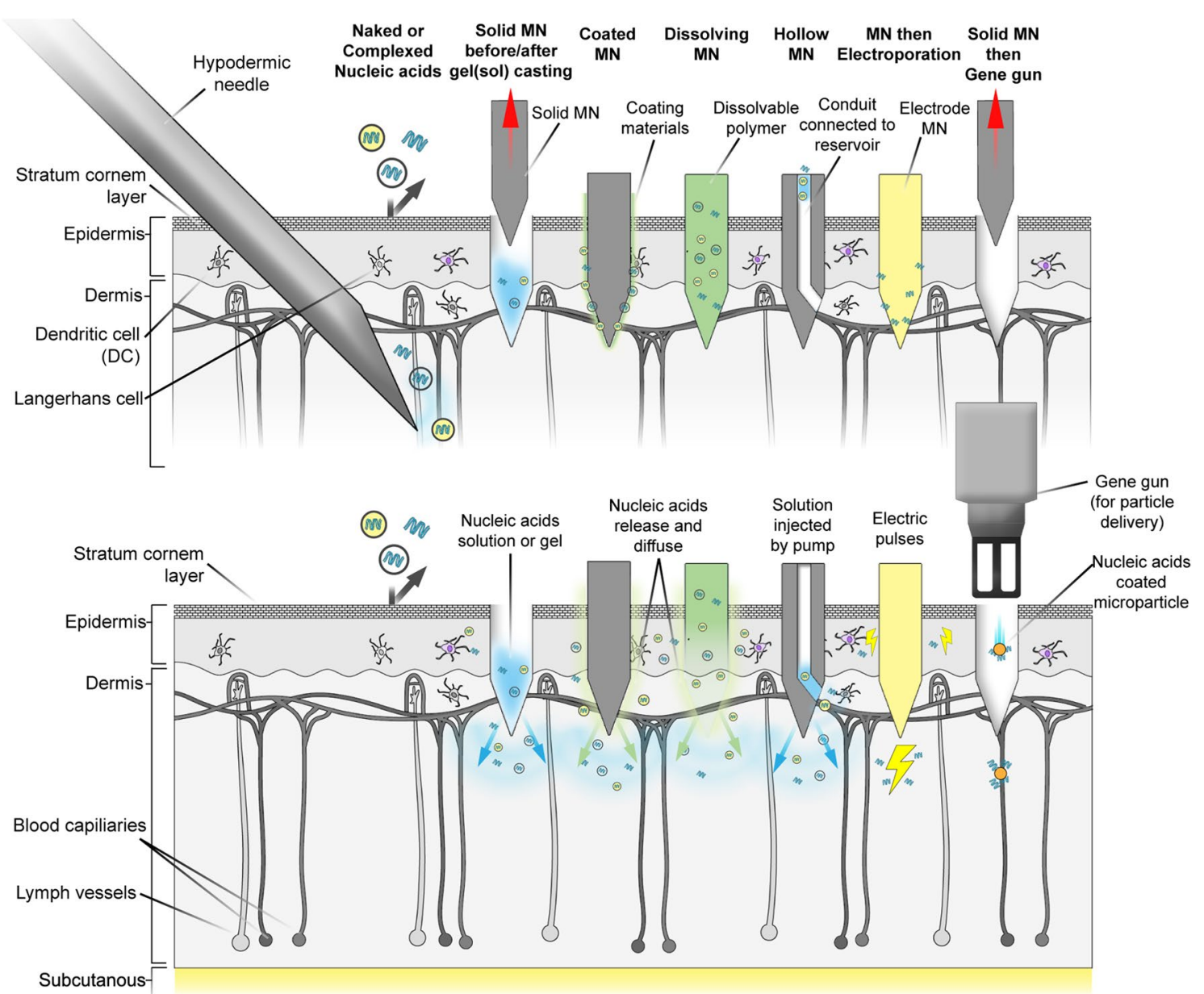

Fig. 2 Schematic configurations of several types of microneedle (MN) systems and physical delivery systems combined with MN for nucleic acid drug delivery [immediately after application (upper) and after drug distribution (lower)]

study using three different heights of dissolving MNs $(400$, 800 , and $1000 \mu \mathrm{m}$ ) (Koh et al. 2018). Similarly, Yan et al. (2014) have examined in vivo expression of reporter genes encoding pDNA by varying the height of solid MN to 0.25 , 0.5 , and $0.75 \mathrm{~mm}$. They also found that longer needles and longer application durations could lead to a more efficient transfection. Wang et al. (2020) have evaluated siRNAloaded dissolving MN by varying the length of the drugloaded tip according to hyaluronic acid concentration and suggested that increasing the length of the tip itself to which the drug is exposed might lead to a more efficient nucleic acid exposure to antigen presenting cells. This suggests that more cell contact induced by longer needles can lead to a more effective expression, although this remains further investigation (Yan et al. 2014; Wang et al. 2020).

Although formulation is a crucial part in any pharmaceutical approach, studies on the formulation of MN associated with nucleic acid therapeutics are very rare, with many unclear parts despite decades of research (Cole et al. 2017). The transfection efficiency of nucleic acid drug in dissolving
$\mathrm{MN}$ formulations can be greatly affected by the type of polymer and the additive content (Kim et al. 2012; Cole et al. 2017; Koh et al. 2018). The most crucial factor to consider is the selection of a polymer that is compatible with nucleic acid. In the case of selecting a biodegradable polymer to fabricate dissolving $\mathrm{MN}$, available options are quite restricted, with the risk of DNase and RNase contamination. Because further contamination is possible during the fabrication process of microneedle, the integrity of the nucleic acid must be validated when blending with polymer and after fabrication of microneedle. It should be noted, however, that the transfection efficiency of a nucleic acid might be significantly diminished by several polymers, even when the nucleic acid integrity in the formulation is adequate. In a nucleic acid MN formulation research, the recovery and integrity of pDNA encapsulated in MNs was evaluated by screening four polymers utilized in the manufacturing process of soluble MNs that can form complex with reporter gene-encoding pDNA through RALA peptide (Cole et al. 2017). In addition, the efficiency of in vitro transfection was evaluated. According 
to molecular weight, two varieties of polyvinylpyrrolidone (PVP) and two types of polyvinyl alcohol (PVA) were examined in that study. A conformational change of the nucleic acid was observed in the pDNA of the PVP-based formulation after 7 days of fabrication. The pDNA encapsulated in the PVP-based formulation had a lower transfection efficiency than the PVA-based formulation in this regard. In another example, naked mRNA was administered with a dissolving needle using polyvinylpyrrolidone (Koh et al. 2018). Although the mRNA in the PVP-based formulation maintained its integrity for 15 days, the in vivo transfection efficiency decreased as the PVP concentration was increased. In the case of coated $\mathrm{MN}$, carboxymethyl cellulose (CMC) is frequently used to enhance the loading quantity by increasing the viscosity in coated MN. However, according to one research, CMC exhibited a significant decrease in pDNA expression (Kim et al. 2012). Based on the increased particle size of DNA in sodium CMC solution, the authors of this study suggested that DNA aggregation in sodium CMC solution might be the cause of the decrease in transfection efficiency. Because the mechanism of how a polymer influences nucleic acid remains largely unknown, more research is required. Alternatively, in the case of restricted polymer alternatives, screening is necessary to determine the optimum choice that can maximize efficiency.

In the case of coated $\mathrm{MN}$ formulation, improvements have been made not only in the coating process, but also in the coating technique and $\mathrm{MN}$ structure to enhance the limited dose and transfection efficiency. To increase the dose of a nucleic acid drug, which was previously considered to be a limitation of coated MN, the number of dipping (Pearton et al. 2012), nanopatterning (Jung et al. 2017), multilayered coating system (Demuth et al. 2013; Kim et al. 2014; Seok et al. 2017), and other parameters have been examined. The multiple dipping method, as described in the coated MN section, significantly increased the nucleic acid loading dosage to about $100 \mu \mathrm{g}$. However, as the number of dips increased, the nucleic acid dose uniformity appeared to deteriorate, and the performance of MN may be affected by changes in $\mathrm{MN}$ shape caused by coating, such as sharpness (Pearton et al. 2012; Vora et al. 2018).

A salinized layer with multiple amine groups that show a partially positive charge was introduced to the surface of coated MN to constitute a multilayer with nucleic acid to improve coating efficiency by utilizing the negative charge of nucleic acid in research on multilayered (layer-by-layer) coated MN (Seok et al. 2017). Kim et al. (2014) also fabricated coated MNs by assembling positively charged albumin and negatively charged heparin on the $\mathrm{MN}$ surface at $\mathrm{pH}$ 4.0. The authors demonstrated $\mathrm{pH}$-dependent rapid release of plasmid DNA by inducing charge inversion of albumin (isoelectric point of 4.9) to a negative charge at physiological $\mathrm{pH}$. In the Alzheimer's disease vaccination study, the multilayered $\mathrm{MN}$ group had a better immune response than the subcutaneously administered group, indicating that the multilayered MN system was an effective delivery system. However, the impact of the release property, in which the drug is dissolved from the MN itself, on transfection efficiency is still insufficient in detailed theory. In one study, the MN system with sustained release properties of nucleic acid produced a better immune response than intramuscular vaccination (Kumar et al. 2012). Thus, further research on release properties is needed.

Several studies on effects of MN components on the stability of encapsulated nucleic acid on the surface or inside of MN have revealed that several disaccharides (trehalose, sucrose, maltose) (Pearton et al. 2012; Seok et al. 2017; Yang et al. 2017; Cole et al. 2018), carbohydrate-enriched formulations (Chong et al. 2013), and some polymers (Cole et al. 2017) can increase stability. Simultaneously, as the use of non-viral carriers, particularly lipid nanoparticles, increases, new strategies for improving stability are required (Schoenmaker et al. 2021). The approach might involve the use of antioxidants or chelators to control catalysis by reactive oxygen species (ROS) and metal ions, or it could involve formulation of helper lipids required for LNP stability (Pardi et al. 2018). The issue of mRNA stability has recently grown severe enough to impact the availability of nucleic acid medications beyond conventional storage and shipping issues, highlighting the importance of ensuring stability which demands constant attention (Schoenmaker et al. 2021).

\section{Combined system with other nucleic acid delivery systems}

With a few exceptions, many MN-based nucleic acid delivery systems coupled with other non-viral vectors or physical delivery systems such as electroporation and gene guns show improved performance compared to MN-based naked nucleic acids.

Nucleic acid complexed with non-viral vectors, notably cationic lipoplex such as DOTAP (Haigh et al. 2014; Bellefroid et al. 2019; Liang et al. 2020), lipofectamine (Saurer et al. 2010; Kim et al. 2012; Pearton et al. 2012; Chong et al. 2013; Yan et al. 2014; Dul et al. 2017; Pamornpathomkul et al. 2017, 2018; Yang et al. 2017), cationic polymer such as polyethylenimine (PEI) (Yin et al. 2013; Hu et al. 2014; Yan et al. 2014; Jung et al. 2017; Liao et al. 2017; Seok et al. 2017; Duong et al. 2018b; Pan et al. 2018; Li et al. 2019b, 2021), and RALA peptide (McCaffrey et al. 2016; Ali et al. 2017; Cole et al. 2017, 2018, 2019) have been reported. The LNP system was designed after several characterizations based on the vector to nucleic acid ratio (such as gel retardation assay, particle size, zeta-potential). Welldesigned nanocarriers for nucleic acids have demonstrated better transfection efficiency in most cases than naked ones 
in vitro and in vivo. In recent years, many nucleic acid delivery systems have employed ionizable LNP including cholesterol and PEG-lipids due to their low toxicity and great efficiency compared to conventional cationic LNPs. However, they have not yet been combined with MN system. Nonviral vector systems are developed constantly. Significant safety concern about an LNP system has just been resolved through worldwide inoculation. More advanced vectors with MN may show promising future, considering the synergistic impact of several current non-viral vector combined systems. Nevertheless, in a study of Yan et al. (2014), a nucleic acid drug solution was casted and then motorized solid MN was administered with naked, lipoplexed (lipofectamine), or polyplexed (PEI) with reporter-gene expressing pDNA on rat skin tissue in vivo. Results revealed that naked pDNA via solid MN was expressed the most efficiently. However, given the considerable amount of evidence showing that a combined system has better results, this case may suggest the importance of a well-designed nanocarrier system even when variables might have influences. In addition, in the case of lipoplex, it is possible to impair transfection efficiency by forming aggregates in the process of drying or storage (Chong et al. 2013). Thus, it is also important to examine the effect of drying or carriers that occurs during the manufacturing process of $\mathrm{MN}$ on the stability of the system (Crommelin et al. 2021).

Studies utilizing a combination of MN systems with other physical methods such as gene guns (Gill et al. 2010; Zhang et al. 2013, 2014, 2015) or electroporation (Hooper et al. 2007; Choi et al. 2010, 2012; Daugimont et al. 2010; Lee et al. 2011; Wei et al. 2014; Pamornpathomkul et al. 2017; Huang et al. 2018) have been reported, leading to a substantial improvement in permeation (Pamornpathomkul et al. 2017) or transfection efficiency compared to a single method (Lee et al. 2011; Choi et al. 2012; Huang et al. 2018). To increase the delivery efficiency of nucleic acid drugs, the convergence of an MN system with various physical delivery technologies should be continuously studied and developed.

\section{Limitations and considerations}

Despite their great potential, there are several considerations and challenges that must be overcome before microneedles for nucleic acid delivery can be commercialized and used in clinical. First, nucleic acid drug stability in the microneedle should be considered. Biopharmaceuticals that are dispersed in liquid formulations frequently promote degradation, and there is also a risk of microbial growth. The dissolving $\mathrm{MN}$ or coated MN could minimize these stability issues by removing the solvent, making it a viable strategy for extending nucleic acid shelf life (Pearton et al. 2012; Demuth et al. 2013; Cole et al. 2017; Tucak et al. 2020). However, even if the nucleic acid integrity in the formulation is adequate, several polymers can significantly reduce the transfection efficiency of a nucleic acid (Kim et al. 2012; Cole et al. 2017; Koh et al. 2018). More research is needed because the mechanism by which polymers influence nucleic acids is largely unknown. Furthermore, optimal MN formulations that can stabilize nucleic acids at room temperature, as well as appropriate sterilization processes that do not damage the nucleic acids in MN, must be developed. Second, the MN delivery system should be reproducible to deliver defined amounts of nucleic acid drugs consistently. Patient-related parameters such as age, gender, and patient condition influence the amount of drug delivered because the skin penetration rate of the microneedle varies depending on pressing force and training experience. To minimize the impact on the relevant patient-related parameters, optimizing the geometry and arrangement of the MN (Makvandi et al. 2021), as well as the development of the applicator (Lahiji et al. 2015), should be considered. Moreover, biomimetic microneedles can improve drug delivery reproducibility by increasing needle adhesion (Han et al. 2020), and drug localization at the needle tip (Jun et al. 2018; Li et al. 2019a) can reduce patient-related variables.

\section{Conclusion}

In recent years, nucleic acid drugs have shown great promise beyond the limitation of conventional small molecules or protein therapeutics. In particular, recent vaccination research and current COVID-19 pandemic highlight the importance of nucleic acid therapies as a novel vaccination platform, unlike the conventional vaccine development system with huge limitation in rapidly responding to emerging infectious diseases with constraints of regulation, development, and production. As a result, there is a growing demand for more advanced nucleic acid drugs that can quickly respond to various diseases including infection, cancer, and intractable diseases.

Nucleic acid drugs shown so far are promising. However, they have shown limited stability related to recent cold-chain storage issues (Schoenmaker et al. 2021). They also need to improve their efficacies. Furthermore, the growing severity of epidemics highlights the need for more effective, selfapplicable, and safe delivery methods. MN-mediated nucleic acid drug delivery is a promising platform for painless and less invasive nucleic acid drug delivery. Compared to the traditional injection approach, it shows enhanced efficacy and improved patient convenience through self-administration with less pain. It also shows increased stability derived from a dried encapsulation, offering a potential alternative to deliver nucleic acid drugs. However, MN systems also face a number of challenges. As with recent mRNA vaccination, 
relevant regulations must be revised. If clinical relevance is established with efficient manufacturing technology and standardization of repeatable systems, this promise will be realized in the future.

Acknowledgements This research was supported by a Grant (NRF2018R1D1A1B07049971) of the Basic Science Research Program through the National Research Foundation (NRF) funded by the Ministry of Education, Science and Technology, Republic of Korea.

\section{Declarations}

Conflict of interest The authors (I. Noh, K. Lee, and Y.S. Rhee) declare that they have no conflict of interest.

Research involving human and/or animal participants This article does not contain any studies with human participants or animals performed by any of the authors.

\section{References}

Ahmad A, Khan JM, Haque S (2019) Strategies in the design of endosomolytic agents for facilitating endosomal escape in nanoparticles. Biochimie 160:61-75. https://doi.org/10.1016/j.biochi. 2019.02.012

Ali AA, McCrudden CM, McCaffrey J et al (2017) DNA vaccination for cervical cancer; a novel technology platform of RALA mediated gene delivery via polymeric microneedles. Nanomed Nanotechnol Biol Med 13:921-932. https://doi.org/10.1016/j. nano.2016.11.019

Arora A, Prausnitz MR, Mitragotri S (2008) Micro-scale devices for transdermal drug delivery. Int J Pharm 364:227-236. https://doi. org/10.1016/j.ijpharm.2008.08.032

Bae WG, Ko H, So JY et al (2019) Snake fang-inspired stamping patch for transdermal delivery of liquid formulations. Sci Transl Med 11:1-12. https://doi.org/10.1126/scitranslmed.aaw3329

Bellefroid C, Lechanteur A, Evrard B et al (2019) In vitro skin penetration enhancement techniques: A combined approach of ethosomes and microneedles. Int J Pharm 572:118793. https://doi. org/10.1016/j.ijpharm.2019.118793

Bernelin-Cottet C, Urien C, McCaffrey J et al (2019) Electroporation of a nanoparticle-associated DNA vaccine induces higher inflammation and immunity compared to its delivery with microneedle patches in pigs. J Control Release 308:14-28. https://doi.org/10. 1016/j.jconrel.2019.06.041

Birchall J, Coulman S, Pearton M et al (2005) Cutaneous DNA delivery and gene expression in ex vivo human skin explants via wet-etch microfabricated microneedles. J Drug Target 13:415-421. https:// doi.org/10.1080/10611860500383705

Cárcamo-Martínez Á, Mallon B, Domínguez-Robles J et al (2021) Hollow microneedles: a perspective in biomedical applications. Int J Pharm 599:120455. https://doi.org/10.1016/j.ijpharm.2021. 120455

Chabri F, Bouris K, Jones T et al (2004) Microfabricated silicon microneedles for nonviral cutaneous gene delivery. Br J Dermatol 150:869-877. https://doi.org/10.1111/j.1365-2133.2004.05921.x

Chen W, Li H, Shi D et al (2016) Microneedles as a delivery system for gene therapy. Front Pharmacol. https://doi.org/10.3389/fphar. 2016.00137
Cho WG, Albuquerque RJC, Kleinman ME et al (2009) Small interfering RNA-induced TLR3 activation inhibits blood and lymphatic vessel growth. Proc Natl Acad Sci U S A 106:7137-7142. https:// doi.org/10.1073/pnas.0812317106

Choi SO, Kim YC, Lee JW et al (2012) Intracellular protein delivery and gene transfection by electroporation using a microneedle electrode array. Small 8:1081-1091. https://doi.org/10.1002/ smll.201101747

Choi SO, Kim YC, Park JH et al (2010) An electrically active microneedle array for electroporation. Biomed Microdevices 12:263-273. https://doi.org/10.1007/s10544-009-9381-x

Chong RHE, Gonzalez-Gonzalez E, Lara MF et al (2013) Gene silencing following siRNA delivery to skin via coated steel microneedles: In vitro and in vivo proof-of-concept. J Control Release 166:211-219. https://doi.org/10.1016/j.jconrel.2012.12.030

Cole G, Ali AA, McCrudden CM et al (2018) DNA vaccination for cervical cancer: Strategic optimisation of RALA mediated gene delivery from a biodegradable microneedle system. Eur J Pharm Biopharm 127:288-297. https://doi.org/10.1016/j.ejpb.2018.02. 029

Cole G, Ali AA, McErlean E et al (2019) DNA vaccination via RALA nanoparticles in a microneedle delivery system induces a potent immune response against the endogenous prostate cancer stem cell antigen. Acta Biomater 96:480-490. https://doi.org/10. 1016/j.actbio.2019.07.003

Cole G, McCaffrey J, Ali AA et al (2017) Dissolving microneedles for DNA vaccination: improving functionality via polymer characterization and RALA complexation. Hum Vaccines Immunother 13:50-62. https://doi.org/10.1080/21645515.2016.1248008

Coulman S, Barrow D, Anstey A et al (2005) Minimally invasive cutaneous delivery of macromolecules and plasmid DNA via microneedles. Curr Drug Deliv 3:65-75. https://doi.org/10.2174/ 156720106775197510

Crommelin DJA, Anchordoquy TJ, Volkin DB et al (2021) Addressing the cold reality of mRNA vaccine stability. J Pharm Sci 110:9971001. https://doi.org/10.1016/j.xphs.2020.12.006

Cullis PR, Hope MJ (2017) Lipid nanoparticle systems for enabling gene therapies. Mol Ther 25:1467-1475. https://doi.org/10. 1016/j.ymthe.2017.03.013

Dagan N, Barda N, Kepten E et al (2021) BNT162b2 mRNA Covid19 Vaccine in a Nationwide Mass Vaccination Setting. N Engl J Med 384:1412-1423. https://doi.org/10.1056/nejmoa2101765

Daugimont L, Baron N, Vandermeulen G et al (2010) Hollow microneedle arrays for intradermal drug delivery and DNA electroporation. J Membr Biol 236:117-125. https://doi.org/10.1007/ s00232-010-9283-0

Demuth PC, Min Y, Huang B et al (2013) Polymer multilayer tattooing for enhanced DNA vaccination. Nat Mater 12:367-376. https:// doi.org/10.1038/nmat3550

Deng Y, Chen J, Zhao Y et al (2016) Transdermal delivery of siRNA through microneedle array. Sci Rep 6:1-8. https://doi.org/10. 1038/srep21422

Depelsenaire ACI, Meliga SC, Mcneilly CL et al (2014) Colocalization of cell death with antigen deposition in skin enhances vaccine immunogenicity. J Invest Dermatol. https://doi.org/10.1038/jid. 2014.174

Dul M, Stefanidou M, Porta P et al (2017) Hydrodynamic gene delivery in human skin using a hollow microneedle device. J Control Release 265:120-131. https://doi.org/10.1016/j.jconrel.2017.02. 028

Duong HTT, Kim NW, Thambi T et al (2018a) Microneedle arrays coated with charge reversal $\mathrm{pH}$-sensitive copolymers improve antigen presenting cells-homing DNA vaccine delivery and immune responses. J Control Release 269:225-234. https://doi. org/10.1016/j.jconrel.2017.11.025 
Duong HTT, Yin Y, Thambi T et al (2018b) Smart vaccine delivery based on microneedle arrays decorated with ultra-pH-responsive copolymers for cancer immunotherapy. Biomaterials 185:13-24. https://doi.org/10.1016/j.biomaterials.2018.09.008

Duong HTT, Yin Y, Thambi T et al (2020) Highly potent intradermal vaccination by an array of dissolving microneedle polypeptide cocktails for cancer immunotherapy. J Mater Chem B 8:11711181. https://doi.org/10.1039/c9tb02175b

Eusébio D, Neves AR, Costa D et al (2021) Methods to improve the immunogenicity of plasmid DNA vaccines. Drug Discov Today. https://doi.org/10.1016/j.drudis.2021.06.008

Fernando GJP, Zhang J, Ng HI et al (2016) Influenza nucleoprotein DNA vaccination by a skin targeted, dry coated, densely packed microprojection array (Nanopatch) induces potent antibody and CD8+ T cell responses. J Control Release 237:35-41. https://doi. org/10.1016/j.jconrel.2016.06.045

Fire A, Xu S, Montgomery MK et al (1998) Potent and specific genetic interference by double-stranded RNA in Caenorhabditis elegans. Nature 391:806-811. https://doi.org/10.1038/35888

Gill HS, Prausnitz MR (2007) Coated microneedles for transdermal delivery. J Control Release 117:227-237. https://doi.org/10. 1016/j.jconrel.2006.10.017

Gill HS, Söderholm J, Prausnitz MR, Sällberg M (2010) Cutaneous vaccination using microneedles coated with hepatitis C DNA vaccine. Gene Ther 17:811-814. https://doi.org/10.1038/gt.2010. 22

Gilleron J, Querbes W, Zeigerer A et al (2013) Image-based analysis of lipid nanoparticle-mediated siRNA delivery, intracellular trafficking and endosomal escape. Nat Biotechnol 31:638-646. https://doi.org/10.1038/nbt.2612

Gittard SD, Chen B, Xu H, et al (2013) The effects of geometry on skin penetration and failure of polymer microneedles. 27:227-243. https://doi.org/10.1080/01694243.2012.705101

Golombek S, Pilz M, Steinle H et al (2018) Intradermal delivery of synthetic mRNA using hollow microneedles for efficient and rapid production of exogenous proteins in skin. Mol Ther Nucleic Acids 11:382-392. https://doi.org/10.1016/j.omtn.2018.03.005

González-González E, Kim YC, Speaker TJ et al (2011) Visualization of plasmid delivery to keratinocytes in mouse and human epidermis. Sci Rep 1:1-9. https://doi.org/10.1038/srep00158

Haigh O, Depelsenaire ACI, Meliga SC et al (2014) CXCL1 gene silencing in skin using liposome-encapsulated siRNA delivered by microprojection array. J Control Release 194:148-156. https:// doi.org/10.1016/j.jconrel.2014.08.021

Han D, Morde RS, Mariani S et al (2020) 4D printing of a bioinspired microneedle array with backward-facing barbs for enhanced tissue adhesion. Adv Funct Mater. https://doi.org/10.1002/adfm. 201909197

Hardee CL, Arévalo-Soliz LM, Hornstein BD, Zechiedrich L (2017) Advances in non-viral DNA vectors for gene therapy. Genes (Basel). https://doi.org/10.3390/genes8020065

Haynes BF (2021) A new vaccine to battle Covid-19. N Engl J Med 384:470-471. https://doi.org/10.1056/nejme2035557

Heil F (2004) Species-Specific Recognition of Single-Stranded RNA via Toll-like Receptor 7 and 8. Science (-80) 303:1526-1529. https://doi.org/10.1126/science. 1093620

Herrera M, Kim J, Eygeris Y et al (2021) Illuminating endosomal escape of polymorphic lipid nanoparticles that boost mRNA delivery. Biomater Sci 9:4289-4300. https://doi.org/10.1039/ d0bm01947j

Hickerson RP, Wey WC, Rimm DL et al (2013) Gene silencing in skin after deposition of self-delivery siRNA with a motorized microneedle array device. Mol Ther Nucleic Acids 2:e129. https://doi.org/10.1038/mtna.2013.56

Hooper JW, Golden JW, Ferro AM, King AD (2007) Smallpox DNA vaccine delivered by novel skin electroporation device protects mice against intranasal poxvirus challenge. Vaccine 25:1814 1823. https://doi.org/10.1016/j.vaccine.2006.11.017

Hu B, Zhong L, Weng Y et al (2020) Therapeutic siRNA: state of the art. Signal Transduct Target Ther. https://doi.org/10.1038/ s41392-020-0207-x

Hu Y, Xu B, Ji Q et al (2014) A mannosylated cell-penetrating peptidegraft-polyethylenimine as a gene delivery vector. Biomaterials 35:4236-4246. https://doi.org/10.1016/j.biomaterials.2014.01. 065

Huang D, Zhao D, Wang X et al (2018) Efficient delivery of nucleic acid molecules into skin by combined use of microneedle roller and flexible interdigitated electroporation array. Theranostics 8:2361-2376. https://doi.org/10.7150/thno.23438

Huang Y, Hong J, Zheng S et al (2011) Elimination pathways of systemically delivered siRNA. Mol Ther 19:381-385. https://doi. org/10.1038/mt.2010.266

Ingrole RSJ, Gill HS (2019) Microneedle coating methods: a review with a perspective. J Pharmacol Exp Ther 370:555-569. https:// doi.org/10.1124/jpet.119.258707

I-Hong Hsu S (2016) Microneedle patch use among those with needle phobia-are all needles the same? Int J Vaccines Vaccin https://doi.org/10.15406/ijvv.2016.02.00038

Jun H, Ahn MH, Choi IJ et al (2018) Immediate separation of microneedle tips from base array during skin insertion for instantaneous drug delivery. RSC Adv 8:17786-17796. https:// doi.org/10.1039/c8ra02334d

Jung D, Rejinold NS, Kwak JE et al (2017) Nano-patterning of a stainless steel microneedle surface to improve the dip-coating efficiency of a DNA vaccine and its immune response. Colloids Surf B 159:54-61. https://doi.org/10.1016/j.colsurfb. 2017.07.059

Karikó K, Muramatsu H, Ludwig J, Weissman D (2011) Generating the optimal mRNA for therapy: HPLC purification eliminates immune activation and improves translation of nucleoside-modified, protein-encoding mRNA. Nucleic Acids Res 39:e142-e142. https://doi.org/10.1093/nar/gkr695

Karikó K, Muramatsu H, Welsh FA et al (2008) Incorporation of pseudouridine into mRNA yields superior nonimmunogenic vector with increased translational capacity and biological stability. Mol Ther 16:1833-1840. https://doi.org/10.1038/ mt.2008.200

Karow M, Chavez CL, Farruggio AP et al (2011) Site-specific recombinase strategy to create induced pluripotent stem cells efficiently with plasmid DNA. Stem Cells 29:1696-1704. https://doi.org/ 10.1002/stem.730

Kaushik S, Hord AH, Denson DD et al (2001) Lack of pain associated with microfabricated microneedles. Anesth Analg. https://doi. org/10.1097/00000539-200102000-00041

Khvorova A, Watts JK (2017) The chemical evolution of oligonucleotide therapies of clinical utility. Nat Biotechnol 35:238-248. https://doi.org/10.1038/nbt.3765

Kim J, Narayana A, Patel S, Sahay G (2019) Advances in intracellular delivery through supramolecular self-assembly of oligonucleotides and peptides. Theranostics 9:3191-3212. https://doi.org/ 10.7150/thno.33921

Kim NW, Lee MS, Kim KR et al (2014) Polyplex-releasing microneedles for enhanced cutaneous delivery of DNA vaccine. J Control Release 179:11-17. https://doi.org/10.1016/j.jconrel.2014.01.016

Kim YC, Song JM, Lipatov AS et al (2012) Increased immunogenicity of avian influenza DNA vaccine delivered to the skin using a microneedle patch. Eur J Pharm Biopharm 81:239-247. https:// doi.org/10.1016/j.ejpb.2012.03.010

Kim YC, Yoo DG, Compans RW et al (2013) Cross-protection by coimmunization with influenza hemagglutinin DNA and inactivated virus vaccine using coated microneedles. J Control Release 172:579-588. https://doi.org/10.1016/j.jconrel.2013.04.016 
Kines RC, Zarnitsyn V, Johnson TR et al (2015) Vaccination with human papillomavirus pseudovirus-encapsidated plasmids targeted to skin using microneedles. PLoS ONE 10:1-18. https:// doi.org/10.1371/journal.pone.0120797

Koh KJ, Liu Y, Lim SH et al (2018) Formulation, characterization and evaluation of mRNA-loaded dissolvable polymeric microneedles (RNApatch). Sci Rep 8:1-11. https://doi.org/10.1038/ s41598-018-30290-3

Kulkarni JA, Cullis PR, Van Der Meel R (2018) Lipid nanoparticles enabling gene therapies: from concepts to clinical utility. Nucleic Acid Ther 28:146-157. https://doi.org/10.1089/nat.2018.0721

Kumar A, Wonganan P, Sandoval MA et al (2012) Microneedle-mediated transcutaneous immunization with plasmid DNA coated on cationic PLGA nanoparticles. J Control Release 163:230-239. https://doi.org/10.1016/j.jconrel.2012.08.011

Kwon H, Kim M, Seo Y et al (2018) Emergence of synthetic mRNA: In vitro synthesis of mRNA and its applications in regenerative medicine. Biomaterials 156:172-193. https://doi.org/10.1016/j. biomaterials.2017.11.034

Lahiji SF, Dangol M, Jung H (2015) A patchless dissolving microneedle delivery system enabling rapid and efficient transdermal drug delivery. Sci Rep 5:1-7. https://doi.org/10.1038/srep07914

Lee K, Kim JD, Lee CY et al (2011) A high-capacity, hybrid electromicroneedle for in-situ cutaneous gene transfer. Biomaterials 32:7705-7710. https://doi.org/10.1016/j.biomaterials.2011.06. 058

Li W, Terry RN, Tang J et al (2019a) Rapidly separable microneedle patch for the sustained release of a contraceptive. Nat Biomed Eng 3:220-229. https://doi.org/10.1038/s41551-018-0337-4

Li X, Xu Q, Wang J et al (2021) A gene-coated microneedle patch based on industrialized ultrasonic spraying technology with a polycation vector to improve antitumor efficacy. J Mater Chem B 9:5528-5536. https://doi.org/10.1039/D1TB00512J

Li X, Xu Q, Zhang P et al (2019b) Cutaneous microenvironment responsive microneedle patch for rapid gene release to treat subdermal tumor. J Control Release 314:72-80. https://doi.org/10. 1016/j.jconrel.2019.10.016

Liang XJ, Zhang JL, Ou HL et al (2020) Skin delivery of siRNA using sponge spicules in combination with cationic flexible liposomes. Mol Ther Nucleic Acids 20:639-648. https://doi.org/10.1016/j. omtn.2020.04.003

Liao JF, Lee JC, Lin CK et al (2017) Self-assembly DNA polyplex vaccine inside dissolving microneedles for high-potency intradermal vaccination. Theranostics 7:2593-2605. https://doi.org/ 10.7150/thno. 19894

Liu G, Deng Y, Song Y et al (2021) Transdermal delivery of adipocyte phospholipase A2 siRNA using microneedles to treat thyroid associated ophthalmopathy-related proptosis. Cell Transplant 30:1-8. https://doi.org/10.1177/09636897211010633

Liu MA (2019) A comparison of plasmid DNA and mRNA as vaccine technologies. Vaccines. https://doi.org/10.3390/vaccines7020037

Lopes A, Vandermeulen G, Préat V (2019) Cancer DNA vaccines: current preclinical and clinical developments and future perspectives. J Exp Clin Cancer Res 38:1-24. https://doi.org/10.1186/ s13046-019-1154-7

Ma Y, Tao W, Krebs SJ et al (2014) Vaccine delivery to the oral cavity using coated microneedles induces systemic and mucosal immunity. Pharm Res 31:2393-2403. https://doi.org/10.1007/ s11095-014-1335-1

Makvandi P, Kirkby M, Hutton ARJ et al (2021) Engineering microneedle patches for improved penetration: analysis, skin models and factors affecting needle insertion. Springer, Singapore

Mansoor I, Lai J, Ranamukhaarachchi S et al (2015) A microneedlebased method for the characterization of diffusion in skin tissue using doxorubicin as a model drug. Biomed Microdevices. https://doi.org/10.1007/s10544-015-9967-4
Martanto W, Davis SP, Holiday NR et al (2004) Transdermal delivery of insulin using microneedles in vivo. Pharm Res 21:947-952. https://doi.org/10.1023/B:PHAM.0000029282.44140.2e

McCaffrey J, Donnelly RF, McCarthy HO (2015) Microneedles: an innovative platform for gene delivery. Drug Deliv Transl Res 5:424-437. https://doi.org/10.1007/s13346-015-0243-1

McCaffrey J, McCrudden CM, Ali AA et al (2016) Transcending epithelial and intracellular biological barriers; a prototype DNA delivery device. J Control Release 226:238-247. https://doi.org/ 10.1016/j.jconrel.2016.02.023

McClements ME, Maclaren RE (2017) Adeno-associated virus (AAV) dual vector strategies for gene therapy encoding large transgenes. Yale J Biol Med 90:611-623

Moreno E, Schwartz J, Calvo A et al (2017) Skin vaccination using microneedles coated with a plasmid DNA cocktail encoding nucleosomal histones of Leishmania spp. Int J Pharm 533:236244. https://doi.org/10.1016/j.ijpharm.2017.09.055

Morshed M, Hasan A, Sharifi M et al (2020) Non-viral delivery systems of DNA into stem cells: Promising and multifarious actions for regenerative medicine. J Drug Deliv Sci Technol 60:101861. https://doi.org/10.1016/j.jddst.2020.101861

Mulligan RC (1993) The basic science of gene therapy. Science (80-) 260:926-932. https://doi.org/10.1126/science.8493530

Osborn MF, Khvorova A (2018) Improving siRNA delivery in vivo through lipid conjugation. Nucleic Acid Ther 28:128-136. https://doi.org/10.1089/nat.2018.0725

Pack DW, Hoffman AS, Pun S, Stayton PS (2005) Design and development of polymers for gene delivery. Nat Rev Drug Discov 4:581-593. https://doi.org/10.1038/nrd1775

Pamornpathomkul B, Niyomtham N, Yingyongnarongkul BE et al (2018) Cationic niosomes for enhanced skin immunization of plasmid DNA-encoding ovalbumin via hollow microneedles. AAPS PharmSciTech 19:481-488. https://doi.org/10.1208/ s12249-017-0855-5

Pamornpathomkul B, Wongkajornsilp A, Laiwattanapaisal W et al (2017) A combined approach of hollow microneedles and nanocarriers for skin immunization with plasmid DNA encoding ovalbumin. Int J Nanomed 12:885-898. https://doi.org/10.2147/ IJN.S125945

Pan J, Ruan W, Qin M et al (2018) Intradermal delivery of STAT3 siRNA to treat melanoma via dissolving microneedles. Sci Rep 8:1-11. https://doi.org/10.1038/s41598-018-19463-2

Pardi N, Hogan MJ, Porter FW, Weissman D (2018) mRNA vaccinesa new era in vaccinology. Nat Rev Drug Discov 17:261-279. https://doi.org/10.1038/nrd.2017.243

Patel S, Kim J, Herrera M et al (2019) Brief update on endocytosis of nanomedicines. Adv Drug Deliv Rev 144:90-111. https://doi. org/10.1016/j.addr.2019.08.004

Pearton M, Saller V, Coulman SA et al (2012) Microneedle delivery of plasmid DNA to living human skin: formulation coating, skin insertion and gene expression. J Control Release 160:561-569. https://doi.org/10.1016/j.jconrel.2012.04.005

Polack FP, Thomas SJ, Kitchin N et al (2020) Safety and efficacy of the BNT162b2 mRNA Covid-19 vaccine. N Engl J Med 383:26032615. https://doi.org/10.1056/nejmoa2034577

Prow TW, Chen X, Prow NA et al (2010) Nanopatch-targeted skin vaccination against West Nile virus and chikungunya virus in mice. Small 6:1776-1784. https://doi.org/10.1002/smll.201000331

Qiu Y, Guo L, Zhang S et al (2016) DNA-based vaccination against hepatitis B virus using dissolving microneedle arrays adjuvanted by cationic liposomes and CpG ODN. Drug Deliv 23:2391-2398. https://doi.org/10.3109/10717544.2014.992497

Ramamoorth M, Narvekar A (2015) Non viral vectors in gene therapy—an overview. J Clin Diagnostic Res 9:GE01-GE06. https:// doi.org/10.7860/JCDR/2015/10443.5394 
Ruan W, Zhai Y, Yu K et al (2018) Coated microneedles mediated intradermal delivery of octaarginine/BRAF siRNA nanocomplexes for anti-melanoma treatment. Int J Pharm 553:298-309. https://doi.org/10.1016/j.ijpharm.2018.10.043

Sahin U, Karikó K, Türeci Ö (2014) MRNA-based therapeutics-developing a new class of drugs. Nat Rev Drug Discov 13:759-780. https://doi.org/10.1038/nrd4278

Saurer EM, Flessner RM, Sullivan SP et al (2010) Layer-by-layer assembly of DNA- and protein-containing films on microneedles for drug delivery to the skin. Biomacromol 11:3136-3143. https://doi.org/10.1021/bm1009443

Schleef M (2013) Minicircle and Miniplasmid DNA Vectors: The Future of Nonviral and Viral Gene Transfer. In: Minicircle Miniplasmid DNA Vectors Futur. Nonviral Viral Gene Transf. https:// books.google.co.kr/books? $\mathrm{hl}=\mathrm{ko} \& \mathrm{lr}=\& \mathrm{id}=\mathrm{Y} 3 \mathrm{tROlqDdX8C} \&$ $\mathrm{oi}=$ fnd $\&$ pg $=$ PT6\& ots $=\mathrm{xUtcD} 6 \mathrm{bNZ}-\&$ sig $=$ fbCVguXfArxgG$\mathrm{vVu}-\mathrm{GOcX} 2 \mathrm{MoxS} 8 \&$ redir_esc $=\mathrm{y} \# \mathrm{v}=$ onepage $\& \mathrm{q} \& \mathrm{f}=$ false. Accessed 4 Sept 2021

Schoenmaker L, Witzigmann D, Kulkarni JA et al (2021) mRNAlipid nanoparticle COVID-19 vaccines: Structure and stability. Int J Pharm 601:120586. https://doi.org/10.1016/j.ijpharm.2021. 120586

Seok HY, Noh JY, Lee DY et al (2017) Effective humoral immune response from a H1N1 DNA vaccine delivered to the skin by microneedles coated with PLGA-based cationic nanoparticles. J Control Release 265:66-74. https://doi.org/10.1016/j.jconrel. 2017.04.027

Setten RL, Rossi JJ, Ping HS (2019) The current state and future directions of RNAi-based therapeutics. Nat Rev Drug Discov 18:421446. https://doi.org/10.1038/s41573-019-0017-4

Song JM, Kim YC, Eunju O et al (2012) DNA vaccination in the skin using microneedles improves protection against influenza. Mol Ther 20:1472-1480. https://doi.org/10.1038/mt.2012.69

Sorrentino S (2010) The eight human "canonical" ribonucleases: molecular diversity, catalytic properties, and special biological actions of the enzyme proteins. FEBS Lett 584:2194-2200. https://doi.org/10.1016/j.febslet.2010.04.018

Takeuchi A, Nomoto Y, Watanabe M et al (2016) Application of microneedles to skin induces activation of epidermal Langerhans cells and dermal dendritic cells in mice. Biol Pharm Bull 39:1309-1318. https://doi.org/10.1248/bpb.b16-00113

Tucak A, Sirbubalo M, Hindija L et al (2020) Microneedles: Characteristics, materials, production methods and commercial development. Micromachines 11:1-30. https://doi.org/10.3390/mi111 10961

Vora LK, Vavia PR, Larrañeta E et al (2018) Novel nanosuspensionbased dissolving microneedle arrays for transdermal delivery of a hydrophobic drug. J Interdisc Nanomed 3:89-101. https://doi. org/10.1002/jin2.41

Wang M, Han Y, Yu X et al (2020) Upconversion nanoparticle powered microneedle patches for transdermal delivery of siRNA. Adv Healthc Mater 9:1-11. https://doi.org/10.1002/adhm.201900635

Wang QL, Ren JW, Chen BZ et al (2018) Effect of humidity on mechanical properties of dissolving microneedles for transdermal drug delivery. J Ind Eng Chem 59:251-258. https://doi.org/ 10.1016/j.jiec.2017.10.030

Wei Z, Zheng S, Wang R et al (2014) A flexible microneedle array as low-voltage electroporation electrodes for in vivo DNA and siRNA delivery. Lab Chip 14:4093-4102. https://doi.org/10. 1039/c4lc00800f
Wolff JA, Malone RW, Williams P et al (1990) Direct gene transfer into mouse muscle in vivo. Science (80-) 247:1465-1468. https://doi. org/10.1126/science. 1690918

$\mathrm{Xu}$ J, Xu B, Tao J et al (2017) Microneedle-assisted, DC-targeted codelivery of pTRP-2 and adjuvant of paclitaxel for transcutaneous immunotherapy. Small 13:1-13. https://doi.org/10.1002/smll. 201700666

Xu Q, Li X, Zhang P, Wang Y (2020) Rapidly dissolving microneedle patch for synergistic gene and photothermal therapy of subcutaneous tumor. J Mater Chem B 8:4331-4339. https://doi.org/10. 1039/d0tb00105h

Yan G, Arelly N, Farhan N et al (2014) Enhancing DNA delivery into the skin with a motorized microneedle device. Eur J Pharm Sci 52:215-222. https://doi.org/10.1016/j.ejps.2013.11.015

Yan Q, Cheng Z, Liu H et al (2018) Enhancement of Ag85B DNA vaccine immunogenicity against tuberculosis by dissolving microneedles in mice. Vaccine 36:4471-4476. https://doi.org/ 10.1016/j.vaccine.2018.06.025

Yang HW, Ye L, Guo XD et al (2017) Ebola vaccination using a DNA vaccine coated on PLGA-PLL/ $\gamma$ PGA nanoparticles administered using a microneedle patch. Adv Healthc Mater 6:1-7. https://doi. org/10.1002/adhm.201600750

Yew NS, Zhao H, Wu IH et al (2000) Reduced inflammatory response to plasmid DNA vectors by elimination and inhibition of immunostimulatory CpG motifs. Mol Ther 1:255-262. https://doi.org/ $10.1006 / \mathrm{mthe} .2000 .0036$

Yin D, Liang W, Xing S et al (2013) Hepatitis B DNA vaccine-polycation nano-complexes enhancing immune response by percutaneous administration with microneedle. Biol Pharm Bull 36:12831291. https://doi.org/10.1248/bpb.b13-00050

Zhang D, Das DB, Rielly CD (2013) An experimental study of microneedle-assisted microparticle delivery. J Pharm Sci 102:3632-3644. https://doi.org/10.1002/jps.23665

Zhang D, Das DB, Rielly CD (2014) Microneedle Assisted MicroParticle Delivery from Gene Guns: experiments using skinmimicking agarose gel. J Pharm Sci 103:613-627. https://doi. org/10.1002/jps.23835

Zhang D, Rielly CD, Das DB (2015) Microneedle-Assisted microparticle delivery by gene guns: Experiments and modeling on the effects of particle characteristics. Drug Deliv 22:335-350. https://doi.org/10.3109/10717544.2014.887158

Zhang MM, Bahal R, Rasmussen TP et al (2021) The growth of siRNA-based therapeutics: Updated clinical studies. Biochem Pharmacol. https://doi.org/10.1016/j.bcp.2021.114432

Zhang S, Zhao S, Jin X et al (2018) Microneedles Improve the Immunogenicity of DNA Vaccines. Hum Gene Ther 29:1004-1010. https://doi.org/10.1089/hum.2018.073

Zhou Q, Wang F, Yang F et al (2010) Augmented humoral and cellular immune response of hepatitis B virus DNA vaccine by micro-needle vaccination using Flt3 $\mathrm{L}$ as an adjuvant. Vaccine 28:1357-1362. https://doi.org/10.1016/j.vaccine.2009.11.006

Publisher's Note Springer Nature remains neutral with regard to jurisdictional claims in published maps and institutional affiliations. 